\title{
Örgütler Arası Ağların Stratejik Önemine Dair Literatürdeki Güncel Tartışmalar
}

\author{
Current Discussions in the Literature on the Strategic Importance of Interorganizational Networks
}

\author{
Murat ÇUBUKCU \\ Dr., Uludağ Üniversitesi, SBE, \\ Işletme A.B.D., mcubukcu16@gmail.com \\ https://orcid.org/0000-0001-9170-4852
}

\author{
Makale Başvuru Tarihi: 19.07.2021 \\ Makale Kabul Tarihi: 03.12.2021 \\ Makale Türü: Araştırma Makalesi
}

$\begin{aligned} & \text { Anahtar } \\ & \text { Kelimeler: }\end{aligned}$
Ağlar,
Stratejik Ağlar,
Örgütler Arası
Ağlar,

A ğlar,

Keywords:

Networks,

Strategic Networks,

Inter Organizational Networks,

\section{ÖZET}

Sosyal ă̆ teorisinde, insan ve insan olmayan varlıkların bir ă̆ düzeneği içerisindeki ilişki ve bağlantılarının örgütlerin performanslarında olumlu fark yaratabildikleri akademik yazında üzerinde önemle durulan konulardan biridir. Bu çalışma, örgüt teorisi literatüründe ăg düzenekleri içerisine yerleşmiş örgütlerin, bu ă̆ düzenekleri dışındaki örgütlerin sahip olamayacağ kaynak ve bilgilere ulaşabileceği konuları üzerine literatürdeki tartışmalara odaklanmaktadır. Literatürde, ne tür örgütler arası ağların mevcut olduğu ve örgütlerin bu ağlara katılma nedenleri hakkındaki tartışmaları tespit etmek ve aynı zamanda ilgili alan yazınına anlamlı bir katkı sunmak amaçlanmıştır. Bu amaçla, belirli bir tarih aralığında ve kasti örnekleme yöntemi ile seçilen uluslararası akademik dergilerdeki örgütler arası ağların stratejik önemi konusundaki tartışmalar bir arada tablo şeklinde, mevcut tartışma konularının ve ulaşılan bulguların tespit edilmesi yoluyla, literatürdeki tartı̧̧malar ışı̆̆ında sunulmuştur. Çalışmada konu hakkındaki literatürdeki tartışmalar ortaya konulmuştur. Bu çalışmada konu ile ilgili yorum yapmak ve yeni sentezlere ulaşmak için literatür taramasından elde edilen sonuçlar kronolojik olarak sıralanmış ve bir tabloda birleştirilmiştir. Bu çalışmada konu ile ilgili kaynaklar gözden geçirilerek, çeşitli görüş ve tutumlara yer verilmiştir. Bu makalede literatür taraması yöntemi kullanılmıştır. Literatür taramasıyla, örgütler arası ağlar konusundaki tartışmaların incelenmesi sonucunda, ilgili kaynakların gözden geçirilmesi, görüşler, tutumlar ve betimlemelerin bulunması sağlanmıştır. Farklı kişilerin aynı konu hakkındaki tartışma konularına ve bulgularına yer verilmiştir. Bu çalışma, örgütsel ağlara dair literatürdeki ă̆ konusundaki kasti örnekleme yöntemi ile seçilen bazı akademik makalelerdeki temel tartışma konularını ve temel bulgularını anlamak için literatüre teorik bir çerçevede katkıda bulunur. Yapılan literatür taraması sonucunda, örgütler arası ăgların stratejik önemi konusunun yaygın bir tartışma alanı olduğu görülmüş̧ür.

\begin{abstract}
In social network theory, it is one of the issues that are emphasized in the academic literature that the relationships and connections of human and non-human beings within a network mechanism can make a positive difference in the performance of organizations. This study focuses on the discussions in the literature on the issues in which organizations located in network mechanisms can access resources and information that organizations outside of these network mechanisms cannot have in the literature of organization theory. In the literature, it is aimed to identify the debates about what kind of inter-organizational networks exist and the reasons for organizations to join these networks, and also to make a meaningful contribution to the relevant literature. For this purpose, the discussions on the strategic importance of inter-organizational networks in international academic journals selected with the deliberate sampling method in a certain date range are presented in the form of a table, in the light of the discussions in the literature, by determining the current discussion topics and the findings reached. In the study, the discussions in the literature on the subject were revealed. In this study, the results obtained from the literature review were arranged chronologically and combined in a table in order to comment on the subject and reach new syntheses. In this study, various opinions and attitudes are included by reviewing the sources related to the subject. In this article, literature review method was used. As a result of examining the discussions on inter-organizational networks with the literature review, it was ensured that the relevant sources were reviewed, opinions, attitudes and descriptions were found. Discussion topics and findings of different people on the same subject are included. This study contributes to the literature in a theoretical framework in order to understand the main discussion topics and main findings in some academic articles selected by the deliberate sampling method on the network in the literature on organizational networks. As a result of the literature review, it was seen that the strategic importance of inter-organizational networks is a common area of discussion.
\end{abstract}




\section{GIRISs}

Ağların stratejik önemi ve sosyal ağların stratejik avantaj elde etmek için kullanılması konuları, literatürde sıklıkla tartışılan hususlar arasında yer almaktadır. Literatürde sosyal ağlardan stratejik avantaj devşirme konusunda tartışmalar mevcuttur. Örgütlerin ve girişimcilerin belirli bir yapı içerisinde sosyal ağ ilişkilerinden ne tür faydalar sağladıkları konusu tartışılagelmiştir. Bu çalışmada örgütsel alanda örgütün içinde bulunduğu ağ düzeneklerine dair oluşan geniş yazına dayanarak, örgütler arası ağlar konusundaki tartışma konularının ve temel bulguların tespiti amaçlanmıştır. $\mathrm{Bu}$ doğrultuda kasti örnekleme yöntemi ile belirlenen akademik makalelerdeki birçok farklı tartışma konuları ve bulguları incelenmiş, araştırma yöntemi olarak içerik ve betimsel analiz yöntemleri benimsenmiştir.

Çalışmamızda literatür taramasıyla ilgili mevcut çalışmalardan alıntılar yapılarak tartışmalar sunulmuştur. İçerik analizi yapılarak; farklı araştırmacıların örgütler arası ağlar hakkındaki düşünceleri aktarılmıştır. Literatür taraması ile örgütler arası ağlar konusundaki temel tartışma konuları ve bulgularının toplanması, toplanan verilerin konuyla ilişkisinin kurulması ve bilginin sınıflandırılmasından oluşan süreç işletilmiştir. Konu ile ilgili kaynakların gözden geçirilmesi sonucu, ilgili görüş ve betimlemelerin bulunması yoluyla tablolar şeklinde karşılaştırmalar yapılmıştır.

Literatür taraması ile örgütler arası ağlar konusuna ilişkin, akademik dergilerde önceden nelerin yazıldığı, konunun önceden işlenen yönleri, konuya ilişkin problemin boyutları, önceki araştırmalardaki araştırma soruları, ulaşılan bulgular ve çıkarılan sonuçlar tespit edilmiştir. Sosyal ağların aktörler ve örgütler için önemi, Granovetter (1973, 1983, 1985), Uzzi (1997, 1999), Burt (1992, 2004), Coleman (1988) ve Sargut (2006) gibi birçok araştırmacı tarafından kullanılan farklı yöntemler, bakış açıları ve iş kolları dikkate alınarak ortaya konulmuştur. Akademik yazında ă̆ düzenekleri içerisinde bulunmanın örgütlerin performansları üzerinde olumlu katk1 sağladığı yönünde hâkim bir görüş olduğu tespit edilmiştir. Bu araştırmalara dayanılarak, sosyal sermaye ve sosyal ağ araştırmalarının işletme literatüründe giderek daha büyük önem kazandığı görülmüştür.

\section{AĞ VE AĞ ÖRGÜTÜ İLE İLGILİ TEORIKK YAPI VE LITTERATÜR ANALİİ}

Literatürde ağ ve ağ örgütü kavramları; üretken faaliyetlerin koordinasyonunu düşünmek, anlamak ve kavramsallaştırmak için ortaya çıkmış kavramlardan biridir (Miersch, 2017:473). Yeni ekonominin getirdiği ăg örgütleri (Miles ve Snow, 1995:5) ve ağ düşüncesinin örgütsel fenomenleri, mikro seviyeden makroya doğru uzanan ve genellikle örgütsel biliş, örgütsel davranış, örgütsel teori ve stratejik yönetim gibi alanlarda ele alınan konuları içerir (Kilduff ve Tsai, 2003:4). A ğ yaklaşımının temelleri sosyoloji ve ekonomi gibi çeşitli disiplinlere dayanmaktadır (Katz vd., 2004:311). Ağ yaklaşımı, ağlara katılmayı ya da ayrılmayı kolaylaştırmak ya da geciktirmek olarak işlem maliyetlerine daha fazla önem verilmesinin gerektiğini önermektedir (Thorelli, 1986:42).

A $\breve{g}$ kavramı hem metafor hem de metodoloji olarak örgüt çalışmalarında güçlü bir yer edinmiştir (Morgan, 1997:2). Büyük ölçüde sosyolojideki yapısal analizden kaynaklı, Tichy vd. (1979) gibi örgüt çalışmalarındaki araştırmacıların çoğu bir ağı, köşe kümesi ve bir köşe arasındaki ilişkiyi gösteren bir dizi kenar olarak tanımlamaktadır. Köşeler; uygulamada düğümler, kenarlar, bağlantılar veya bağlar olarak da adlandırılmaktadır (Blaschke vd., 2012:885).

Castells (1996, 2000), ağların; yeni örgütlenmelerin yapıldığg ya da yapılacağı temel unsurlardan birisi olduğunu savunmuştur. Powell ve Dimaggio (1991)'e göre ağlar, çağdaş toplumlarda ve ekonomik sistemde önemli bir rol oynamaktadır (Miersch, 2017:474). Ağda, işletmeler hem kısıtlanabilir hem de firsatlar elde edebilirler (Axelsson ve Easton, 1992:185). Genel olarak bir ağ; düğümler veya konumlardan, pozisyonlar arasındaki etkileşimle tezahür eden bağlantılar olarak görülebilir (Thorelli, 1986:38). Örgütler arası bir ağ, birimlerin toplanmasından farklı olan işletmeler arasındaki karşılıklı bağımlılı̆̆ düzenleyen bir moddur (Garandori ve Soda, 1995:184). Benson (1975)'e göre örgütler arası ağ; iki kıt kaynağın, paranın ve otoritenin dağıtımıyla ilgili politik bir ekonomi olarak düşünülebilir (Thorelli, 1986:39).

Literatürde işletmeler arası ağın birçok biçimi olan ortak girişimler, franchising, konsorsiyum ve ticari anlaşmalar gibi konular gözden geçirilmiş ve ele alınmıştır (Grandori ve Soda, 1995:198). Örgütler; ortak girişimler, stratejik ortaklıklar ve franchising gibi ağ uygulamaları oluştururlar ve bu uygulamaları kullanırlar (Özkan Canbolat, 2008:13). Literatürde çoğunlukla iş kollarında geliştirilen ve strateji çalışmalarıyla yakından 
ilişkili olan özellikle ortak girişimler gibi örgütlenmiş ittifaklar (Killing, 1983; Harrigan, 1985) ve Franchising (Pilotti ve Pozzana, 1990) örgütlenmesinin doğrudan ele alındığı tespit edilmiştir (Grandori ve Soda, 1995:187).

Stratejik yönetim perspektifini temsil eden Nalebuff ve Brandenburger (1997), Dyer ve Nobeoka (2000), Möller vd. (2005) gibi akademisyenler, kaynaklar ve yetenekler görüşü ile stratejik ağlarla ilgilenmişlerdir. Stratejik ağlar hem yatay hem de dikey aktörler ile stratejik ilişki kurmakta ve yönetilmektedir (Partanen ve Möller, 2012:482). Stratejik ağ perspektifi 2003-2007 yılları arasında Möller ve meslektaşları tarafindan tanıtılmıştır (Möller ve Halinen, 2017:6).

Örgütlerin sürdürebilir rekabet avantajına sahip olmalarında, mevcut kaynakları çok önemli ve etkilidir. Örgüt kaynaklarının sınırlı, nadir ve taklit edilmesinin zor olması onları değerli kılar (Barney, 1991:105). Barney ve Wright (1998:43) beşerî sermaye becerileri, çalışan bağlılığı ve kültür gibi insan kaynaklarının işlevlerinin sürdürülebilir rekabet avantajının kaynă̆ı olduğunu iddia etmişlerdir (Gerhart, 2009:245).

Sosyal sermayenin ve özellikle de pozitif psikolojik sermayenin, diğer sermaye türlerine göre sürdürülebilir rekabet üstünlüğü sağlanmasında, rakipler tarafından taklit edilmesi zor olması gibi nedenlerle daha etkili olduğunu iddia eden çeşitli araştırmalar vardır. Bazı araştırmalarda, sosyal ağlar geliştirmenin örtülü bilginin işletmenin varlığg haline dönüştürülerek, rekabet üstünlügünün elde edilmesinde pozitif sermaye yaratılarak, sinerjik bir etki yaratabildiği ortaya konulmuştur (Luthans vd., 2006:387; Luthans, 2007:541).

Kaynak tabanlı görüşe göre stratejik ağların kurulması, işletmelerin risklerini paylaşmalarına, temel rekabet güçlerini geliştirmelerine ve iki taraflı yenilikleri teşvik etmelerine yardımcı olan kaynakları, teknolojileri ve bilgileri (Gulati vd.,, 2000) elde etmelerini sağlar (Xie ve Gao, 2018:812-814). İşletmelerin faaliyetlerininin devamlılığı ve sürdürülebilir rekabet avantajı sağlayabilmeleri için gerekli değişimleri, stratejilerini ve yapılarını değiştirerek, çevreye hızla uyum sağlamalarını gerektirir (Burton ve Obel, 2004:2).

Örgütler, sürekli değişen çevreyle karşılıklı etkileşim içerisinde bulunan sosyal varlıklardır ve çevreleriyle uyum sağlayarak çalışmak zorundadırlar (Özdevecioğlu, 1995:120). Miles ve Snow (1984) da örgütü dinamik bir varlık olarak görmüşlerdir. Luo ve Park (2001) örgütün strateji ve yapı ile çevre arasındaki bağlantıların oluşturulması ve sürdürülmesine yönelik örgütler arası bir ilişki olarak makro uyumun ve strateji, yap1 ya da kurum içi ilişkiler arasında güçlü bir ilişkinin geliştirilmesi içinde mikro uyumun sağlanması gerektiğini iddia etmişlerdir (Aleksic ve Jelavic, 2017:89).

Granovetter (1985), Coleman (1990), White (1992) ve Burt (1997) gibi sosyal sermaye kavramına ve yerleşiklik tartışmalarına farklı açıklamalar getiren bir grup sosyal ağ düzeneği araştırmacıları ağ düzeneği kavramlarının biçimlendirilmesi ve görgül olarak test edilmesinde başı çekmişlerdir (Seibert vd., 2001:220). Granovetter (1973, 1985), Coleman (1988), Burt (1992), Gulati ve Gargiulo (1999) ortaya koydukları örgütler arası ağlara ilişkin farklı çalışmalarla literatüre önemli katkılar sağlamışlardır. Coleman (1988), Burt (1992), Uzzi (1996) ve Kogut (2000) gibi araştırmacılar ağ düzeneklerini açık ve kapalı yapılar olarak ayırmışlardır (Walker vd., 1997:111).

Granovetter (1973)'a göre mikro ve makro arasındaki köprünün kurulması bakımından ağ düzeneklerinin analiz edilmesi önemlidir (Granovetter, 1973:1360). Ağ yapısı, endüstrinin yerleşik olduğu genel ilişki modelini ifade eder (Gulati vd., 2000:205). Granovetter (1985) gibi sosyologlar, örgütlerin sosyal ağlardaki yerleşikliklerine göre neden davrandıklarını açıklarken önemli bir ilerleme kaydetmişlerdir. Ancak bu ağların nasıl ortaya çıktığını nadiren incelemişlerdir. Pfeffer ve Salancik (1978) ile Burt (1983) gibi örgütsel sosyologlar, tipik olarak toplumsal yapı gibi dışsal faktörler tarafından yönlendirilen ağ oluşumunu incelemişlerdir.

\section{AĞLARA İLIŞKİN ULUSLARARASI LITERATÜRDEKİ GÜNCEL TARTIŞMALAR}

Oliver ve Ebers (1998), 1980'den 1996'ya kadar dört önde gelen dergide yayınlanan 158 makalede ağ analiziyle sonuçlanan bir literatür taraması yapmışlardır. Araştırmalarına göre, bu alandaki en sık kullanılan teoriler kaynak bağımlılığı, politik güç ve ağ yaklaşımlarıdır. Kaynak bağımlılı̆gı teorisi, örgütlerin sistem içindeki kendi güçlerini artırmak için çeşitli stratejiler kullanarak, örneğin bir ağa katılmak gibi çevresel bağımlılıklarını azaltma sürecine odaklanır (Oliver ve Ebers, 1998:563).

Sosyolojik çalışmalarda kaynak bağımlılığı kuramı önem arz eder. Hannan ve Freeman (1977), popülasyon ekolojisi yaklaşımında örgütler arası ilişkilerin ele alınmasıyla, örgüt ve değişim olaylarını incelemişlerdir. Piyasa ekonomisinde etkililik ve ekonomik verimlilik örgütler arası düzenlemelerin seçiminde rol oynar (Grandori ve Soda, 1995:193). 
Kaynak tabanlı bakış açısına göre, değer yaratan kaynakların yaratılması konusunda önemli bir kaynak, işletmelerin ilişki ağında yatar. Bir kaynak olarak ağ yapısı, bir işletmenin ilişkilerinin yapısal modelinin benzersiz olması ve rekabet avantajı sağlama potansiyeline sahip olmasıdır (Gulati vd., 2000:207). Öte yandan kaynak bağımlılı̆̆ı kuramında ise örgütlerin içsel olarak üretemeyecekleri, varlıklarını sürdürebilmeleri için gerekli kaynakları sağlayabilecekleri çevredeki unsurlarla ilişki ve etkileşime girmek zorunda oldukları ileri sürmektedir (Aldrich ve Pfeffer, 1976:79-105).

Araştırmacılar işletmelerin kaynak bağımlılıklarını ya başka örgütlere veya aktörlere bağımlılıklarını azaltan kaynaklara erişim sağlayarak ya da başkalarının onlara bağımlılığını artıran kaynakları elde tutarak yönettiklerini varsaymaktadırlar. Bu bakış açısında sahip Ahuja vd. (2009), Grandori ve Soda (1995), Jack (2010), Lin vd. (2009) gibi araştırmacılar işletmelerin kaynaklara erişimlerini iyileştirmek için ağlarını nasıl yönettiklerini açıklamak üzere ağ teorisini entegre ederek ilgili literatürü zenginleştirmiştir (Sullivan ve Cameron, 2014:554).

Literatürdeki tartı̧̧malarda, sosyal sermayenin işletmelere sağladığı güç üzerinde durulduğu tespit edilmiştir (Burt, 1992). Örgütlerin fiziksel kaynaklara, bilgiye, siyasi gücü elinde bulunduran taraflara ulaşarak hayatlarını devam ettirmelerinde yerleşik ilişkilerin rol oynayabileceğini iddia eden çalışmalar bulunmaktadır (Rao vd., 2000:268). Literatürde bir ortaklığın gelişmesinde köprü olarak bir siyasi bağ kullandığından bahsedilen araştırmalar bulunmaktadır. Benson (1975), örgütler arası ağı iki kıt kaynağın, paranın ve otoritenin dağıtımıyla ilgili politik bir ekonomi olarak tanımlamıştır (Thorelli, 1986:39). Makro kurumsal yaklaşımlar içerisindeki Biggart ve Hamilton'in (1991) otorite yaklaşımı ve Whitley (2000) ulusal iş sistemi yaklaşımları ulusal bazdaki kurumsal bağlamın oluşumunda devletin rolünü vurgulamaktadır.

İş insanlarının bir sosyal ağda elde ettikleri konumları ve sosyal sermayeleri, başarılarında ihtiyaç duyacakları güç ve katkıyı sağlamaktadır (Adler ve Kwon, 2002:31). Örgütler, yaşamsal faaliyetlerini sürdürürken, sadece kaynaklar ve müşteriler için rekabet etmemekte, politik güç ve kurumsal meşruiyet de elde etmeye çalışmaktadırlar (DiMaggio ve Powell, 1983). Ağlar, meşruiyet (Baum ve Oliver, 1991) için stratejik bir faktör olmaktadır (Bae ve Gargiulo, 2003:3). Kurumsal yaklaşıma göre örgütsel meşruiyet daha çok, sosyal olarak inşa edilen bir olgudur (Suchman, 1995:574). Kurumsal yaklaşımda, örgütler arası ağ ilişkilerinde bağımlılık temel kavram olarak ele alınmış, ancak bağımlılık sadece işlemlerden veya malzeme kaynaklarından dolayı değil, meşruiyet için en önemli kaynak olarak gösterilmiştir (Grandori ve Soda, 1995:190).

Shils (2002), merkez ve çevre isimli makalesinde, toplumun yapısında bir merkeze sahip olduğunu, bu topluma üye olmanın bu merkezi bölge ile kurulan ilişki tarafından şekillendirdiğini ifade etmiştir (Shils, 2002:86). Shils (2002), merkez ve çevre kavramlarının her toplumda var olduğunu ve bu kavramların merkez ve onun üstünde belirleyici bir etkiye sahip olduğu varsayılan çevresel bir alanın varlığından bahseder.

A ̆g düzeneği araştırmacıları, yerleşiklik konusundaki araştırmalarında, konuya paradigmatik farklılıklardan kaynaklanan değişik bakış açılanı kazandırmışlardır. Hangi türde ağ ilişkilerinin, aktörlerin sosyal sermayesi olarak tanımlanabildiği ve aktörlerin kendilerine fayda sağlamak ya da diğerlerine göre avantaj kazanmak için ağ düzeneği içerisinde kendilerini nasıl konumlandırmaları gerektirdiği konularında; Granovetter (1973), Bourdieu (1983), Coleman (1988) Burt (1992) ve Podolny'nin (2001) getirdiği kuramsal yaklaşımlarda bu soruların cevapları aranmaktadır. Granovetter $(1973,1983)$ ile Bourdieu (1983), Coleman (1988) ve Podolny (2001) arasında gerçekleşen tartışma, aktörlerin kendilerine fayda sağlamak için güvene dayalı kapalı bir ă̆ düzeneği kümesi içerisinde yer alıp yer almaması konularındadır (Yeloğlu ve Sözen, 2008:244).

Sosyal yerleşiklik iddiası örgütsel ağ çalışmalarından ortaya çıkmıştır. Sosyal yerleşiklik ilk olarak Polanyi $(1944,2001)$ tarafından formüle edilip, daha sonra Granovetter $(1973$, 1985) tarafından geliştirilmiştir. Burt (1992) ve Uzzi (1996) gibi ağ düzeneği araştırmacıları tarafından da ele alınmıştır (Sargut vd., 2007:5). A $\breve{g}$ düzeneği kuramında yerleşiklik iddiası, ekonomik aktörlerin sosyal ilişkiler ile birlikte ağ içerisinde bulunduğunu varsayar (Uzzi ve Lanchester, 2004:320). Uzzi (1997), aktörlerin bulundukları ortamdan bağımsız hareket edemeyecekleri ve çevre ile aktör arasındaki sosyal etkileşimin önemini vurgulayan yerleşiklik yaklaşımına göre, aktörler çevreleriyle güçlü bağlar kurarlar (Kantur, 2017:179). Ekonomik değişimin güç olduğu zamanlarda yerleşiklik daha da önem arz eder (Burt, 1992). Çünkü Burt'e (1992) göre aktörlerin bağlantıları ve ağdaki konumları bir sosyal yapı içerisinde rekabet avantajı sağlayabilmektedir.

Literatürde genel olarak kabul edilen sosyal sermaye tanımına göre, daha iyi bağlantıları olan aktörler daha başarılı olmaktadırlar. Coleman'a göre sosyal sermaye; fiziki sermaye ve beşerî sermayeyi tamamlar (Coleman, 1988:98). Aktörlerin ilişki ve bağlantıları, onlara kaynaklara ulaşma, yenilik ve kalite geliştirme gibi konularda avantaj sağlar (Adler ve Kwon, 2002:17). 
Uluslararası yazında uluslararası akademik indeks ve tarama sitelerinde teorik ve uygulamalara yönelik 1970’li yıllardan günümüze kadar yapılmış olan en eski çalı̧̧malardan en güncel çalışmalara, ilgili literatür taranarak konuyla ilgili kapsamlı bir kavramsal çerçeve oluşturulmuştur. Tablo 1'de uluslararası akademik tarama sitelerinde taranan akademik dergilerde yer alan 80 makalenin başlı̆̆ı, yazarları, konusu ve temel bulguları kronolojik olarak sıralanmış ve yeni araştırmacılara katkı sağlamak için özetlenmiştir.

Tablo 1. Uluslararası Literatürde Ağ Konusundaki Bazı Akademik Makalelerin Temel Konu ve Bulguları

\begin{tabular}{|c|c|c|c|}
\hline Makale Başlığı & $\begin{array}{l}\text { Yazar Adı, } \\
\text { Dergi Adı ve Tarihi }\end{array}$ & Makalenin Temel Konusu & Makalenin Temel Bulguları \\
\hline $\begin{array}{l}\text { Social Network Analysis for } \\
\text { Organizations }\end{array}$ & $\begin{array}{l}\text { TICHY N.M. TUSHMAN } \\
\text { M.L. FOMBRUN C. } \\
\text { The Academy of } \\
\text { Management Review } \\
1979\end{array}$ & $\begin{array}{l}\text { Örgütler için sosyal ağ analizi. } \\
\text { Bu makalede, sosyal ağ } \\
\text { yaklaşımlarının kökenleri, anahtar } \\
\text { kavramlar ve yöntemler } \\
\text { tanıtılmaktadır. }\end{array}$ & $\begin{array}{l}\text { Sosyal ağ perspektifi, veri toplamanın yanı } \\
\text { sıra, veri analizine rehberlik etme noktasında } \\
\text { geliştirilen teorik bir çerçevenin örneğidir. }\end{array}$ \\
\hline $\begin{array}{c}\text { Networks: Between Markets and } \\
\text { Hierarchies }\end{array}$ & $\begin{array}{l}\text { THORELLI H.B. } \\
\text { Strategic Management } \\
\text { Journal } \\
1986\end{array}$ & $\begin{array}{l}\text { Ağ yönetimi bütüncül bir yaklaşım } \\
\text { gerektirir. } \\
\text { A } \text { ğ terimi, uzun vadeli ilişkilere } \\
\text { katılan iki veya daha fazla örgütü } \\
\text { ifade eder. }\end{array}$ & $\begin{array}{l}\text { Bir ağ, büyüme motoru olarak hizmet } \\
\text { edebilmesi için, aynı zamanda hem genel hem } \\
\text { de üye işletmelerde stratejik planlama } \\
\text { gerektirir. Ağların, gelecekte sayı ve } \\
\text { karmaşıklıkta büyümesini bekleyebiliriz. }\end{array}$ \\
\hline $\begin{array}{l}\text { Informal Networks and } \\
\text { Organizational Crises: An } \\
\text { Experimental Simulation }\end{array}$ & $\begin{array}{l}\text { KRACKHARDT D., } \\
\text { STERN R.N. } \\
\text { Social Psychology } \\
\text { Quarterly } \\
1988\end{array}$ & $\begin{array}{l}\text { Bu makale, belirli bir sosyal ağa } \\
\text { yapısına sahip olan kuruluşların, } \\
\text { krizlere cevap vermede daha etkili } \\
\text { olduğu öne sürülmektedir. }\end{array}$ & $\begin{array}{l}\text { Bazı örgütsel teorisyenler, enformel örgütlerin } \\
\text { önemini vurgulamışlardır. } \\
\text { Resmi örgüt, otorite çizgilerini tanımlasa da } \\
\text { etkinin büyük bir kısmı arkadaşların, } \\
\text { temasları gayri resmi yapısıyla } \\
\text { gerçekleştirilir. }\end{array}$ \\
\hline On Strategic Networks & $\begin{array}{l}\text { JARILLO C.J. } \\
\text { Strategic Management } \\
\text { Journal } \\
\text { Jan.-Feb. } 1988\end{array}$ & $\begin{array}{l}\text { Ağ konusu önemli bir konu } \\
\text { olmakla birlikte, genel olarak } \\
\text { kabul edilmiş kavramsal bir } \\
\text { çerçeveden yoksundur. } \\
\text { Ağ konusunda artan ilginin } \\
\text { nedenlerinin ortaya konulmaktadır. }\end{array}$ & $\begin{array}{l}\text { Stratejik ağlar bir organizasyon tarzıdır. } \\
\text { Ağın ekonomik koşullarını, bir ağın var oluş } \\
\text { koşullarını incelemek ve bu varoluş } \\
\text { koşullarının kendi iç tutarlılığı çerçevesinde } \\
\text { analiz etmek hedeflenmektedir. } \\
\text { Ağların yapısı, rekabet stratejisinin temel } \\
\text { paradigması içerisinde uyumlu olması gerekir. }\end{array}$ \\
\hline $\begin{array}{l}\text { Neither Market nor Hierarchy: } \\
\text { Network Forms Of Organization }\end{array}$ & $\begin{array}{c}\text { POWELL W.W. } \\
\text { Research in Organizational } \\
\text { Behavior } \\
\text { January } 1990\end{array}$ & 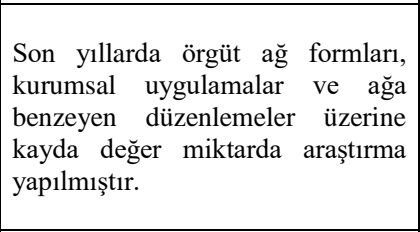 & $\begin{array}{l}\text { Karşıllıklı iletişim kalıları ve değişim örgüsü } \\
\text { ile belirlenmiş örgütlenme ağı, ekonomik bir } \\
\text { örgütlenmenin uygulanabilir bir yapısını } \\
\text { temsil eder. Ağlar, pazar ve hiyerarşik } \\
\text { üstünlük yapılarıyla karşılaştırılır ve ağları } \\
\text { ayırt edici özellikleri vurgulanır. Ağ örgütü } \\
\text { kolayca aktarılabilir. }\end{array}$ \\
\hline $\begin{array}{c}\text { Inter-Firm Networks: } \\
\text { Antecedents, Mechanisms and } \\
\text { Forms }\end{array}$ & $\begin{array}{l}\text { GRANDORI A. SODA G. } \\
\text { Organization Studies } \\
\text { March } 1995\end{array}$ & $\begin{array}{l}\text { İşletme ağları ile ilgili geniş } \\
\text { kapsamlı literatürü gözden geçiren } \\
\text { ve organize etme çabası içerisinde, } \\
\text { onları destekleyen örgütsel } \\
\text { mekanizmaları değerlendirmek } \\
\text { amacıyla ve ağın ortaya çııışını ve } \\
\text { şeklini etkileyen ana değişkenler. }\end{array}$ & $\begin{array}{l}\text { Örgütler arası ağlar, disipliner yaklaşımlarla } \\
\text { çalışabilirler ve böylece sosyal bilimlerin } \\
\text { çeşitli dalları arasında ortak bir ilgi alanı ve } \\
\text { potansiyel diyalog temeli oluşturabilirler. } \\
\text { İşletmeler arası ağ çalışmaları da yaklaşım } \\
\text { türleri çok geniştir. Biz dizi önemli sosyo- } \\
\text { ekonomik örgüt boyutları ve farkl } \\
\text { koordinasyon özellikleri kullanılarak çok } \\
\text { çeşitli ağ biçimleri ve mekanizmaları } \\
\text { tanımlanabilir. }\end{array}$ \\
\hline $\begin{array}{l}\text { Strategic Networks Among Small } \\
\text { Firms: Implications For Strategy } \\
\text { Research Methodology }\end{array}$ & $\begin{array}{l}\text { BORCH O.J., } \\
\text { ARTHUR M.B. } \\
\text { Journal of Management } \\
\text { Studies } \\
\text { July } 1995 \\
\end{array}$ & $\begin{array}{lr}\text { Bu çalışmada, stratejik iş } \\
\text { araştırmalarında örgütsel formların } \\
\text { yönetimini } & \text { anlamada } \\
\text { sağlayabileceği } & \text { katkılara } \\
\text { odaklanılmaktadır. } & \\
\end{array}$ & $\begin{array}{l}\text { Ağ ilişkilerinde güven meselesi önemlidir ve } \\
\text { insanları etkileşimlerde sosyo-kültürel temel } \\
\text { gibi bağlamsal yönler de etkilemektedir. } \\
\text { Ağların sosyal yönlerinin de dikkate alınmasi } \\
\text { gerekir. }\end{array}$ \\
\hline $\begin{array}{l}\text { A General Theory of Network } \\
\text { Governance: Exchange } \\
\text { Conditions and Social } \\
\text { Mechanisms }\end{array}$ & $\begin{array}{l}\text { JONES C. HESTERLY W. } \\
\text { BORGATTI S.P. } \\
\text { Academy of Management } \\
\text { Review } \\
\text { October } 1997\end{array}$ & $\begin{array}{l}\mathrm{Bu} \text { makaledeki amacımız, ağ } \\
\text { yönetişiminin hangi şartlar altında } \\
\text { titizlikle tanımlanmış, } \\
\text { karşılaştırmalı üstünlüğe sahip } \\
\text { olduğunu ve bu nedenle ortaya } \\
\text { çıkması ve gelişmesi olasılığını } \\
\text { açıklayan bir teori sağlamaktır. }\end{array}$ & $\begin{array}{l}\text { Teorimiz, işlem maliyeti ekonomisi ve sosyal } \\
\text { ağ teorilerini bileştirir ve ağ yönetim } \\
\text { biçiminin talep belirsizliği, görev karmaşıklığı } \\
\text { gibi koşullara bir yanıt olduğunu iddia eder. } \\
\text { Bu koşulların tümü yerine getirildiğinde, ağ } \\
\text { yönetişim formunun hem hiyerarşiye hem de } \\
\text { piyasa çözümlerine uyum sağlama, koordine } \\
\text { etme ve değişimleri korumadaki avantajları } \\
\text { vardır. }\end{array}$ \\
\hline $\begin{array}{l}\text { Social Structure and Competition } \\
\text { in Interfirm Networks: The } \\
\text { Paradox of Embeddedness }\end{array}$ & $\begin{array}{l}\text { UZZI B. } \\
\text { Administrative Science } \\
\text { Quarterly } \\
\text { March } 1997\end{array}$ & $\begin{array}{l}\text { Örgütler arası ağlarda sosyal yapı } \\
\text { ve rekabet. Toplumsal yapının, } \\
\text { ekonomik hayatı nasıl etkilediği. }\end{array}$ & $\begin{array}{l}\text { Çoğu örgüt kuramcisı, sosyal yapının } \\
\text { ekonomik davranışta önemli rol oynadığını } \\
\text { düşünürken, birçok ekonomik teorisyen, } \\
\text { sosyal ilişkilerin ekonomik işleyişi asgari } \\
\text { düzeyde etkilediğini belirtmişlerdir. }\end{array}$ \\
\hline Alliances and Networks & $\begin{array}{c}\text { GULATI R. } \\
\text { Strategic Management }\end{array}$ & $\begin{array}{l}\text { Bu makalede, stratejik ittifakların } \\
\text { incelenmesinde bir sosyal ağ }\end{array}$ & $\begin{array}{l}\text { İşletmeler arasındaki stratejik ittifaklar artık } \\
\text { her yerde görülmektedir. Stratejik ittifaklara }\end{array}$ \\
\hline
\end{tabular}




\begin{tabular}{|c|c|c|c|}
\hline & $\begin{array}{c}\text { Journal } \\
\text { April } 1998\end{array}$ & perspektifi tanıtılmaktadır. & $\begin{array}{l}\text { bir sosyal ağ perspektifinin } \\
\text { vurgulamemak için yoğnnlaşmaktadır. }\end{array}$ \\
\hline Starting Up a Strategic Network & $\begin{array}{l}\text { HINTERHUBER H.H., } \\
\text { HIRSCH A. } \\
\text { Thunderbird International } \\
\text { Business Review } \\
\text { May/June } 1998\end{array}$ & $\begin{array}{l}\text { Stratejik bir ağ kurmak, ortak } \\
\text { girişimler, stratejik ittifaklar, } \\
\text { lisanslama, dikey entegrasyon gibi } \\
\text { işletmelerin stratejik ağlarda iş } \\
\text { birliği yapabilmelerinin başka bir } \\
\text { yoludur. }\end{array}$ & $\begin{array}{l}\text { A } \text { ğ oluşturmaya artan ilginin çeşitli nedenleri } \\
\text { vardır. Işletmeler, ağ dışındaki rakiplerine } \\
\text { karşı rekabet avantaj1 kazanmak ya da } \\
\text { sürdürmek için çeşitli stratejik ağlarda yer } \\
\text { almakta ve } \\
\text { konumlandırmaktadırlar. }\end{array}$ \\
\hline $\begin{array}{l}\text { Organizing and Evaluating } \\
\text { Interfirm Networks: A } \\
\text { Structurationist Perspective on } \\
\text { Network Processes and } \\
\text { Effectiveness }\end{array}$ & $\begin{array}{l}\text { SYDOW J. WINDELER A. } \\
\text { Organization Science } \\
\text { May/June } 1998\end{array}$ & 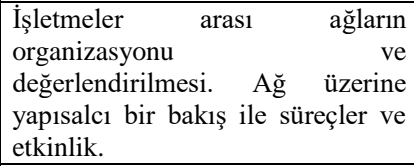 & $\begin{array}{l}\text { Ağ, örgütleri derinden etkiler ve muhtemelen } \\
\text { değiștirir. } \quad \text { Uygulanabilirlik ve ve kabul } \\
\text { edilebilirlik, ag aşletmelerinin r ve } \\
\text { paydaşlarının bazılarının diğerlerine etkililik } \\
\text { kriterlerini empoze etmelerine izin verecektir. }\end{array}$ \\
\hline $\begin{array}{l}\text { Internationalization Strategies, } \\
\text { Networking and Functional } \\
\text { Discretion }\end{array}$ & $\begin{array}{l}\text { JAKLIC Marko, } \\
\text { Competition and Change } \\
\text { December } 1998\end{array}$ & $\begin{array}{l}\text { Uluslararasılaşma stratejileri, ağ ve } \\
\text { işlevsel taklit. } \\
\text { İsletmeler yabancı ağlarda ortaklar } \\
\text { ile ilişsiler kurarak ve geliştirerek } \\
\text { uluslararasılaşıyor. }\end{array}$ & $\begin{array}{l}\text { İşletmeler, yabanc1 ağlarda ortaklar ile } \\
\text { iliş̧kiler kurarak uluslararasılaşırlar. Farklı } \\
\text { ağlarda koordinasyonu artırarak uluslararası } \\
\text { entegrasyonu amaçlarlar. Stratejik iş } \\
\text { yönetiminin başarısı için, başarılı öğrenme } \\
\text { stratejisi ön şarttır. }\end{array}$ \\
\hline $\begin{array}{l}\text { Where Do Interorganizational } \\
\text { Networks Come From? }\end{array}$ & $\begin{array}{l}\text { GULATI R., } \\
\text { GARGIULO M. } \\
\text { American Journal of } \\
\text { Sociology } \\
\text { March } 1999\end{array}$ & $\begin{array}{l}\text { Örgütler kritik kaynaklara erişmek } \\
\text { için birbirleriyle ittifaklar kurarlar. } \\
\text { Örgütler arası ağlar nereden } \\
\text { geliyor? }\end{array}$ & $\begin{array}{l}\text { İttifaklar, var olan ağı değiştirir. Ortaya çıkan } \\
\text { ağ yapısını farklılaşması karşlılılı } \\
\text { bağımlılığn etkisini azaltır. Bu makalede, } \\
\text { örgütsel ağların oluşumunun yerleşik örgütsel } \\
\text { eylemin sonucu olduğu bir model önerilmiştir. } \\
\text { Sosyal yapı ile sistemdeki örgütlerin } \\
\text { davranışları arasında sistematik iki yönlü bir } \\
\text { bağlantı vardır. }\end{array}$ \\
\hline Strategic Networks & $\begin{array}{l}\text { GULATI R. NOHRIA N. } \\
\text { ZAHEER A. } \\
\text { Strategic Management } \\
\text { Journal } \\
\text { March } 2000\end{array}$ & $\begin{array}{l}\text { Stratejik ağlar, kalıcı olan, onlara } \\
\text { katılan işletmeler için stratejik } \\
\text { öneme sahip olan ve stratejik } \\
\text { ittifaklar, ortak girişimler ve } \\
\text { benzer bağları içeren birtakım } \\
\text { bağlardan oluşmaktadır. } \\
\end{array}$ & $\begin{array}{l}\text { İşletmelerin yerleşik oldukları ilişki ağları, } \\
\text { davranışlarını ve performanslarını derinden } \\
\text { etkilemektedir. Bir ağ perspektifi, teknoloji ve } \\
\text { rekabet gibi dinamiklerin daha iyi anlaşılması } \\
\text { için önemli bilgiler sağlayabilir. }\end{array}$ \\
\hline $\begin{array}{l}\text { Trapped in Your Own Net? } \\
\text { Network Cohesion, Structural } \\
\text { Holes and the Adaptation of } \\
\text { Social Capital }\end{array}$ & $\begin{array}{l}\text { GARGIULO M. } \\
\text { BENASSI M. } \\
\text { Organizaiton Sicence } \\
\text { March-April } 2000\end{array}$ & $\begin{array}{l}\text { Ağların sosyal sermaye yaratması. } \\
\text { Ağların kapatılması ve yapısal } \\
\text { boşluk teorisi. }\end{array}$ & $\begin{array}{l}\text { Ağın görev ortamındaki önemli değişikliklere } \\
\text { adapte olması, sosyal sermaye olarak değerini } \\
\text { koruması açısından önemlidir. }\end{array}$ \\
\hline $\begin{array}{c}\text { Embeddedness, Social Identity } \\
\text { and Mobility; Why Firms Leave } \\
\text { the NASDAQ and Join the New } \\
\text { York Stock Exchange }\end{array}$ & $\begin{array}{c}\text { RAO H. } \\
\text { DAVIS G.F. WARD A. } \\
\text { Administrative Science } \\
\text { Quarterly } \\
\text { June } 2000\end{array}$ & $\begin{array}{l}\text { Yerleşiklik, sosyal kimlik ve } \\
\text { Hareketlilik. } \\
\text { Sosyal çevre örgütlerin sosyal } \\
\text { kimliklerini nasıl etkiler? }\end{array}$ & $\begin{array}{l}\text { Örgütler sosyal kimliklerini, resmi gruplara } \\
\text { üye olmaktan sağlarlar ve olumlu bir sosyal } \\
\text { kimliğin sürdürülmesi için çaba gösterirler. } \\
\text { Ağlar bir kimlik kaynağıdır ve yerleşiklik } \\
\text { argümanları içerir. }\end{array}$ \\
\hline $\begin{array}{l}\text { Collaboration Networks, } \\
\text { Structural Holes, and Innovation: } \\
\text { A Longitudinal Study }\end{array}$ & $\begin{array}{c}\text { AHUJA G. } \\
\text { Administrative Science } \\
\text { Quarterly } \\
\text { September } 2000\end{array}$ & $\begin{array}{l}\text { İş birliği ağları, yapısal boşluklar } \\
\text { ve yenilik. }\end{array}$ & $\begin{array}{l}\text { İşletmeler arası örgütlenme ağlarında ki } \\
\text { pozisyonlar, işletme davranışını ve ve } \\
\text { sonuçlarını etkiler. Aktörler, bağlantıllarını } \\
\text { diğerlerine göre bilgi edinmek ve kontrol } \\
\text { avantajları elde etmek için kullanabilirler. }\end{array}$ \\
\hline $\begin{array}{l}\text { The Network as Knowledge } \\
\text { Emergence of Structure: } \\
\text { Generative Rules and }\end{array}$ & $\begin{array}{l}\text { KOGUT B. } \\
\text { Strategic Management } \\
\text { Journal } \\
2000\end{array}$ & $\begin{array}{l}\text { Bir ağ yapısı, rekabetçi } \\
\text { piyasalardaki işletmelere yönelik iş̧ } \\
\text { birliği kararlarına rehberlik eden } \\
\text { kuralların oluşturduğu ortaya çıkan } \\
\text { bir sonuçtur. }\end{array}$ & $\begin{array}{l}\text { İşletme değerinin bir kısmının, iş birliği } \\
\text { yapma kararını veren üretici kuralların } \\
\text { işleyişinden doğan bir ağa katılmasından } \\
\text { kaynaklandığını öne sürüyoruz. }\end{array}$ \\
\hline $\begin{array}{l}\text { Do Networks Really Work? A } \\
\text { Framework for Evaluating Public- } \\
\text { Sector Organizational Networks }\end{array}$ & $\begin{array}{l}\text { PROVAN K.G. } \\
\text { MILWARD B.H. } \\
\text { Public Administration } \\
\text { Review } \\
\text { July/August } 2001\end{array}$ & $\begin{array}{l}\text { Ağlar gerçekten çalışır mı? } \\
\text { Makalede, ağ etkinliğinin genel bir } \\
\text { tartışması sunulmaktadır. }\end{array}$ & $\begin{array}{l}\text { Ağ etkinliğini değerlendirmek, ağların ve ağ } \\
\text { oluşturma biçimlerinin, topluluk üyelerine } \\
\text { gereken hizmetleri sunma da etkili olup } \\
\text { olmadığını anlamak için kritiktir. }\end{array}$ \\
\hline $\begin{array}{l}\text { How Should Companies Interact } \\
\text { in Business Networks? }\end{array}$ & $\begin{array}{l}\text { HAKANSSON H. FORD D. } \\
\text { Journal of Business } \\
\text { Research } \\
\text { February } 2002\end{array}$ & $\begin{array}{l}\text { Stratejistler, ortak girişimler, } \\
\text { stratejik ittifaklar ve stratejik } \\
\text { ağlarla ilgilidirler. }\end{array}$ & $\begin{array}{l}\text { Bir ağ, bir dizi düğümün birbiriyle ilişkili } \\
\text { olduğu bir yapıdır. Işletmeler kendi ağ } \\
\text { konumunu değiştirmeye ve başkalarının } \\
\text { ilişkilerini de etkilemeye çalışmaktır. }\end{array}$ \\
\hline $\begin{array}{l}\text { Network Structure and } \\
\text { Knowledge Transfer: The Effects } \\
\text { of Cohesion and Range }\end{array}$ & $\begin{array}{l}\text { REAGANS R. } \\
\text { MCEVILY B. } \\
\text { Administrative Science } \\
\text { Quarterly } \\
\text { June } 2003\end{array}$ & $\begin{array}{l}\text { Enformel ağları farklı } \\
\text { özelliklerinin bilgi transferini nasıl } \\
\text { etkilediği? } \\
\text { A } \breve{g} \text { yapısı, bilgi aktarım sürecini } \\
\text { nasıl etkiler? }\end{array}$ & $\begin{array}{l}\text { Hem sosyal uyum hem de ağ aralığı, bilgi } \\
\text { transferini kolaylaştırır. } \\
\text { Enformel kisilerarası ağlar, bilgi aktarım } \\
\text { sürecinde kritik rol oynarlar. }\end{array}$ \\
\hline $\begin{array}{l}\text { Interorganizational relationships } \\
\text { and networks: An overview }\end{array}$ & $\begin{array}{l}\text { RITTER T. Gemünden H. } \\
\text { Journal of Business }\end{array}$ & $\begin{array}{l}\text { Ağ düşüncesinin kökleri. Bireysel } \\
\text { işletmeler analizinden, işletmeler }\end{array}$ & $\begin{array}{l}\text { Sanal örgütler, büyüklük etkilerini elde etmek } \\
\text { için kaynaklarını bir araya getiren işletmeler }\end{array}$ \\
\hline
\end{tabular}


ÇUBUKCU, Murat - Örgütler Arası Ağların Stratejik Önemine Dair Literatürdeki Güncel Tartışmalar

\begin{tabular}{|c|c|c|c|}
\hline & $\begin{array}{c}\text { Research } \\
2003\end{array}$ & arasındaki etkileşime. & arasında bir iliş̧i ağı olarak yorumlanabilir. \\
\hline $\begin{array}{c}\text { Strategic Human Resource } \\
\text { Practices, Top Management Team } \\
\text { Social Networks, And Firm } \\
\text { Performance: The Role Of } \\
\text { Human Resource Practices In } \\
\text { Creating Organizational } \\
\text { Competitive Advantage }\end{array}$ & $\begin{array}{c}\text { COLLINS C.J. } \\
\text { CLARK K.D. } \\
\text { Academy Of Management } \\
\text { Journal } \\
2003\end{array}$ & $\begin{array}{lrr}\text { Bu makalede, } & \text { insan } & \text { kaynakları } \\
\text { uygulamaları } & \text { ile } & \text { işletme } \\
\text { performansı arasindaki } & \text { ilişki } \\
\text { keşfedilmektedir. } & \text { Üst } & \text { düzey } \\
\text { yöneticilerin } & & \text { ağlarına } \\
\text { odaklanıyoruz. } & & \end{array}$ & $\begin{array}{l}\text { Daha büyük ağlar, daha fazla bağ içerir. } \\
\text { Ağ aralı̆ğ sosyal ağındaki kişilerin } \\
\text { çeşitliliğini ifade eder. Büyük ağlar } \\
\text { oluşturmak yerine seçici olarak bir dizi dıs } \\
\text { aktörlerle güçlü ve güvene dayalı ilişkiler } \\
\text { kurmak isteyebilirler. }\end{array}$ \\
\hline $\begin{array}{l}\text { Inter-Firm Networks and } \\
\text { Entrepreneurial Behavior: A } \\
\text { Structural Embeddedness } \\
\text { Perspective }\end{array}$ & $\begin{array}{l}\text { SIMSEK Z. LUBATKIN } \\
\text { M.H. FLOYD S.W. } \\
\text { Journal of Management } \\
2003\end{array}$ & $\begin{array}{l}\text { İşletmeler arası ağlar ve } \\
\text { girişimcilik davranışı. } \\
\text { Yapısal yerleşik bir perspektif ve } \\
\text { kavrayıcı bir bakış açısı sunar. }\end{array}$ & $\begin{array}{l}\text { Örgütlerarası ağlar, çevresel durumlara uyum } \\
\text { sağlamak ve değişimleri koordine etmek ve } \\
\text { korumak için örtülü ve açık uçlu sözleşmelere } \\
\text { dayalı ürün veya hizmetler sunmaya çalışan } \\
\text { seçkin, kalıcı ve yapılandırılmış bir özerk } \\
\text { kurumlar kümesidir. }\end{array}$ \\
\hline $\begin{array}{l}\text { Preferential Linkage and Network } \\
\text { Evolution: A Conceptual Model } \\
\text { and Emprical Test in the U.S. } \\
\text { Video Game Sector }\end{array}$ & $\begin{array}{l}\text { VENKATRAMAN V.N., } \\
\text { LEE C. } \\
\text { Academy of Management } \\
\text { Journal } \\
2004\end{array}$ & $\begin{array}{l}\text { Bir ağın yoğunluk ve örtüşme ile } \\
\text { baskınlı ve yerleşiklik gibi ağ } \\
\text { yapısının ve teknoloji } \\
\text { özelliklerinin ürün lanslanmalarını } \\
\text { nasıl şekillendirdiği incelenmiştir. }\end{array}$ & $\begin{array}{l}\text { Bir ağ perspektifi ile değer zinciri boyunca } \\
\text { alıcıları ve/veya tedarikçileri içeren dikey } \\
\text { ilişkilere odaklanılmıştır. Bir ağ perspektifi, } \\
\text { performans farklılıklarını yaratan karmaşık } \\
\text { kaynak akışlarını ve bağımlılıkların, } \\
\text { mantıksal olarak anlamak için güçlü bir } \\
\text { yoldur. }\end{array}$ \\
\hline $\begin{array}{l}\text { Managing in Complex Business } \\
\text { Networks }\end{array}$ & $\begin{array}{l}\text { RITTER T. WILKINSON } \\
\text { I.F. JOHNSTON W.J. } \\
\text { Industrial Marketing } \\
\text { Management } \\
\text { April } 2004\end{array}$ & $\begin{array}{l}\text { İşa ağları ne ölçüde yönetilebilir? } \\
\text { Bir işletmenin bir ağı yönetme } \\
\text { yeteğgi nasıl karakterize edilir ve } \\
\text { ölçülebilir? }\end{array}$ & $\begin{array}{l}\text { Bir işletme, faaliyetlerini hem etkinleştiren } \\
\text { hem de ksıstlayan, devam eden iç ve dış } \\
\text { iliş̧kiler ağına yerleşiktir. } \\
\text { İş ağlarında iş ilişkilerini yönetebilmek çok } \\
\text { önemlidir. }\end{array}$ \\
\hline $\begin{array}{l}\text { Structural vs. Relational } \\
\text { Embeddedness: Social Capital } \\
\text { and Managerial Performance }\end{array}$ & $\begin{array}{c}\text { MORAN P. } \\
\text { Strategic Management } \\
\text { Journal } \\
\text { December } 2005\end{array}$ & $\begin{array}{l}\text { Yöneticilerin iş ilişkisi ağının, yani } \\
\text { sosyal sermayesinin yönetimsel } \\
\text { performans üzerindeki etkisini } \\
\text { incelemektedir. }\end{array}$ & $\begin{array}{l}\text { Sosyal sermayenin yapısal ve ilişkisel } \\
\text { bileşenlerine ayırmanın } \\
\text { vurgulanmaktadır. Sosyal sermayenin çok } \\
\text { yönlü bir doğası vardır. Bir ağ stratejisi } \\
\text { içerisindeki odaklanma ve tutarlıllk, } \\
\text { yöneticilere faydalar sağlar. }\end{array}$ \\
\hline $\begin{array}{c}\text { Structure and Agency? Actor- } \\
\text { Network Theory and Strategic } \\
\text { Organization }\end{array}$ & $\begin{array}{l}\text { STEEN J. COOPMANS C. } \\
\text { WHYTE J. } \\
\text { Strategic Organization } \\
\text { August } 2006\end{array}$ & 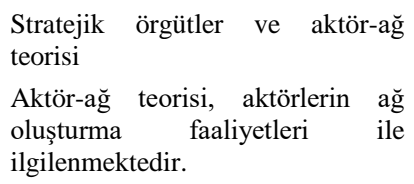 & $\begin{array}{l}\text { İnsan ve insan olmayan aktörlerle ittifak } \\
\text { kurabilmek modern aktörlerin başarılı } \\
\text { olabilmelerine katkı sağlar. }\end{array}$ \\
\hline $\begin{array}{l}\text { Knotting the Action Net or } \\
\text { Organizing Between } \\
\text { Organizations }\end{array}$ & $\begin{array}{c}\text { LINDBERG K. } \\
\text { CZARNIAWSKA B. } \\
\text { Scandinavian Journal of } \\
\text { Management } \\
\text { December } 2006\end{array}$ & $\begin{array}{l}\text { Bir ağ, insanlar ve kuruluşlardan } \\
\text { oluşan, aktörler arasında bir } \\
\text { bağlantı dizisidir. } \\
\text { Başarılı bir örgütlenme sürecinde } \\
\text { farklı eylem türlerinin etkileri. }\end{array}$ & $\begin{array}{l}\text { Mevcut eylem ağları dönüștürülebilir ve } \\
\text { genişletilebilir. Sonuçta örgütün yeniden } \\
\text { yapılandırılmasına yol açabilecektir. } \\
\text { Başarılı bir örgütlenme sürecinde, ilk aktörler } \\
\text { gelir, sonra ağlar ve son olarakta bir ağdaki } \\
\text { eylemler dizisi. }\end{array}$ \\
\hline $\begin{array}{l}\text { Rise of Strategic Nets - New } \\
\text { Modes of Value Creation }\end{array}$ & $\begin{array}{l}\text { MOLLER K. RAJALA A. } \\
\text { Industrial Marketing } \\
\text { Management } \\
\text { October } 2007\end{array}$ & $\begin{array}{l}\text { Ağ adı verilen, kasitlı olarak } \\
\text { oluşturulan iş ağlarının türü ve } \\
\text { yönetimine odaklanılmaktadır. }\end{array}$ & $\begin{array}{l}\text { Ağlar işletmelere çeşitli faydalar sağlamak } \\
\text { için yaygın olarak kullanılır. } \\
\text { Farklı iş ağlarının etkin yönetimi, temel değer } \\
\text { yaratma mantığına bağlı olduğu öne } \\
\text { sürülmektedir. } \\
\text { A ğ, yönetim için çok farklı koşullar ve } \\
\text { gereksinimler sunar. }\end{array}$ \\
\hline $\begin{array}{l}\text { Interfirm Collaboration Networks: } \\
\text { The Impact of Large-Scale } \\
\text { Network Structure on Firm } \\
\text { Innovation }\end{array}$ & $\begin{array}{l}\text { SCHILLING M. } \\
\text { PHELPS C.C. } \\
\text { Management Science } \\
\text { July } 2007\end{array}$ & $\begin{array}{l}\text { İnovasyonda aracı ağların önemi. } \\
\text { Bilgi ağlarında bilgi yaratmayı } \\
\text { anlamak için birçok önemli } \\
\text { katkılar sunmak amaçlanmakta. }\end{array}$ & $\begin{array}{l}\text { İttifak ağlarının yapısı, bilgi yaratma } \\
\text { potansiyelini artırı. Yoğun yerel kümelenme, } \\
\text { iletişim ve iş birliği teşvik edilerek ağda bilgi } \\
\text { aktarma kapasitesinin artması sağlar. }\end{array}$ \\
\hline $\begin{array}{l}\text { Research Collaboration Networks } \\
\text { And Innovation Output }\end{array}$ & $\begin{array}{l}\text { DEMIRKAN İ. DEEDS } \\
\text { D.L. } \\
\text { Academy of Management } \\
\text { Proceedings } \\
\text { August } 2007\end{array}$ & $\begin{array}{l}\text { İşletmelerin araştırmaya dayalı ego } \\
\text { ağlarının gelişimi, zaman içindeki } \\
\text { performanslarını nasıl etkiler? }\end{array}$ & $\begin{array}{l}\text { Literatürde, ağ } \quad \text { özelliklerinin } \\
\text { genişledikçe nasıll değişeceğine ve ağ } \\
\text { oluşturma davranışında nasıl bir değişiklik } \\
\text { gerektirdiğine dair eksiklikler vardır. }\end{array}$ \\
\hline $\begin{array}{c}\text { Modes of Network Governance: } \\
\text { Structure, Management and } \\
\text { Effectiveness }\end{array}$ & $\begin{array}{l}\text { PROVAN K.G. KENIS P. } \\
\text { Journal of Public } \\
\text { Administration Research } \\
\text { and Theory } \\
\text { August } 2007\end{array}$ & $\begin{array}{l}\text { Bu makale, örgütsel ağların } \\
\text { yönetişimini ve yönetişimin ă̆ } \\
\text { etkinliği üzerindeki etkisini } \\
\text { incelemektedir. } \\
\text { Ağ yönetişiminin kritik rolüne ve } \\
\text { ă etkinliği üzerindeki etkisine }\end{array}$ & $\begin{array}{l}\text { Ağlar, çok örgütlü bir yönetişimin önemli bir } \\
\text { biçimi olarak yaygın bir şekilde tanınmıştır. } \\
\text { İlerlemeler rağmen, ağların genel işleyişi } \\
\text { hakkında sahip olduğumuz bilgiler arasında } \\
\text { ciddi tutarsızlıklar vardır. } \\
\text { Ağların işleyişini anlamak önemlidir, çünkü }\end{array}$ \\
\hline
\end{tabular}




\begin{tabular}{|c|c|c|c|}
\hline & & odaklanılmaktadır. & $\begin{array}{l}\text { ağların neden belirli çıktılar ürettiğini daha iyi } \\
\text { anlayabiliriz. }\end{array}$ \\
\hline $\begin{array}{l}\text { Strategic Networks And } \\
\text { Entrepreurial Ventures }\end{array}$ & $\begin{array}{c}\text { STUART T.E. } \\
\text { SORENSON O. } \\
\text { Strategic Entrepreneurship } \\
\text { Journal } \\
\text { December } 2007\end{array}$ & $\begin{array}{l}\text { Bu makalenin } \\
\text { ağlarınusu, girişimcilik sürecini ve } \\
\text { çıktılarını } \\
\text { rolüdür. }\end{array}$ & $\begin{array}{l}\text { Girişimciler sosyal ağlarını kurarlarken } \\
\text { stratejik davranırlar. } \\
\text { Girişimci aktörler ağlarını stratejik olarak } \\
\text { oluştururlar. }\end{array}$ \\
\hline $\begin{array}{l}\text { Organizational Learning: Effects } \\
\text { of (Network) Structure and } \\
\text { (Individual) Strategy }\end{array}$ & $\begin{array}{c}\text { RODAN Si. } \\
\text { Computational and } \\
\text { Mathematical Organization } \\
\text { Theory } \\
\text { September } 2008\end{array}$ & $\begin{array}{l}\text { Örgütsel öğrenmede ağ yapısının } \\
\text { ve stratejilerin etkileri. } \\
\text { Sosyal ağlar, fikir üretme ve } \\
\text { öğrenme konusunda alternatif } \\
\text { stratejilerle kullanılır. }\end{array}$ & $\begin{array}{l}\text { Örgütler deneyimlerinden öğrenirler. Farklı } \\
\text { ağ yapıları ve bireysel öğrenme stratejilerinin } \\
\text { örgütsel düzeydeki etkisi görülmektedir. } \\
\text { Öğrenme, ağdaki ortalama düğüm sayısı ile } \\
\text { artacaktır. }\end{array}$ \\
\hline $\begin{array}{l}\text { Business to Business } \\
\text { Relationships: The Paradox of } \\
\text { Network Constraints? }\end{array}$ & $\begin{array}{l}\text { BALLANTYNE D. } \\
\text { WILLIAMS J.R. } \\
\text { Australasian Marketing } \\
\text { Journal } \\
\text { December } 2008\end{array}$ & \begin{tabular}{lcr} 
Ağlardaki & yönetsel & \multicolumn{2}{c}{ eylemlere } \\
sinırlar & koymuş görünen & üç \\
paradoks & eleştirilmekte & ve \\
alternatif & bakışs & açıları \\
değerlendirilmektedir. &
\end{tabular} & $\begin{array}{l}\text { Ağlar çeşitlilik üzerine inşa edilmiştir. Ancak } \\
\text { buna rağmen sistematik özellikleri vardır. } \\
\text { Yöneticilerin kendi etkileşimleri hakkındaki } \\
\text { sorularının cevapları her zaman belirli duruma } \\
\text { ve içeriğe bağlı olacaktır. }\end{array}$ \\
\hline $\begin{array}{c}\text { Actor-Network Theory, } \\
\text { Organizations and Critique: } \\
\text { Towards a Politics of Organizing }\end{array}$ & $\begin{array}{l}\text { ALCADIPANI R. } \\
\text { HASSARD J. } \\
\text { Organization } \\
2010\end{array}$ & $\begin{array}{l}\text { Aktör ağ teorisi olarak bilinen } \\
\text { sosyal teori yaklaşımı, tartışmalı } \\
\text { bir yaklaşım olarak görülmekte ve } \\
\text { sosyolojik perspektifi teşvik ettiği } \\
\text { görülmektedir. }\end{array}$ & $\begin{array}{l}\text { Aktör-ă̆ teorisi, bilim, teknoloji ve toplum } \\
\text { gibi bir dizi sosyal alanda giderek artan } \\
\text { popüler bir sosyolojik yöntemdir. } \\
\text { Örgütler sadece nesnelerin düzeni içerisinde } \\
\text { değil, çoklu etkileşimlerle de etki yaratılldığ } \\
\text { ima edilmiştir. }\end{array}$ \\
\hline $\begin{array}{l}\text { Network Performance and } \\
\text { Coordination }\end{array}$ & $\begin{array}{l}\text { HERRANZ J. } \\
\text { Public Performance \& } \\
\text { Management Review } \\
\text { March } 2010\end{array}$ & $\begin{array}{l}\text { Ağ performansı için, ağlardaki } \\
\text { etkinlik hakkında farklı araştırma } \\
\text { bulgularının gözden geçirilmesi ve } \\
\text { birleştirilmesinden stratejik bir } \\
\text { koordinasyon çerçevesine katkıya } \\
\text { ihtiyaç bulunmaktadır. }\end{array}$ & $\begin{array}{l}\text { Ağların faydalarını vurgulayan bazı } \\
\text { araştırmalar, genellikle eleştirel olmayan bir } \\
\text { şekilde, işbirlikçi yatay düzenlemelerin } \\
\text { hiyerarşik düzenlemelerle karşılaştırıldığında } \\
\text { avantaj sağladığını varsayılmaktadır. } \\
\text { Kendi kendini organize eden bir ağ bazen } \\
\text { koordinasyonu tanımlamak için bir yaklaşım } \\
\text { olarak sunulmaktadır. }\end{array}$ \\
\hline $\begin{array}{c}\text { How Companies Strategise } \\
\text { Deliberately in Networks Using } \\
\text { Strategic Initiatives }\end{array}$ & $\begin{array}{l}\text { HARRISON D. HOLMEN } \\
\text { E. PEDERSEN A.C. } \\
\text { Industrial Marketing } \\
\text { Management } \\
\text { Aug.-Sept. } 2010\end{array}$ & $\begin{array}{l}\text { Makalenin amacı, ağların kasten } \\
\text { nasıl bir ag ortamında } \\
\text { geliştirildiğini kavramsallaştırmak } \\
\text { ve tartışmaktır. }\end{array}$ & $\begin{array}{l}\text { Bir örgütün yerleşik olduğu ağ, yöneticileri } \\
\text { kadar önemlidir. Ağ bağlamındaki } \\
\text { etkileşimler hem eylemi kısıtlar hem de } \\
\text { etkinleştirir. Bir iş ağına yerleştiğinde odak } \\
\text { noktasının stratejisini düşünmenin bir } \\
\text { yoludur. }\end{array}$ \\
\hline $\begin{array}{l}\text { Actor-Network Theory and the } \\
\text { Dilemma of the Resource } \\
\text { Concept in Strategic Management }\end{array}$ & $\begin{array}{c}\text { STEEN J. } \\
\text { Scandinavian Journal of } \\
\text { Management } \\
\text { September } 2010\end{array}$ & $\begin{array}{l}\text { Bu araştırmanın amacı, kaynaklar } \\
\text { ve strateji arasındaki dinamik bağ } \\
\text { kavramsallaştırmak ve gelecekteki } \\
\text { ampirik araştırmalar için } \\
\text { yönelimleri ortaya çıkarmaktır. }\end{array}$ & $\begin{array}{l}\text { Aktör-ağ teorisi, kaynakları yapılandıran bir } \\
\text { sosyoloji dalından, kaynakları yapılandıran } \\
\text { kuruluşlar içindeki ilişkiler hakkında farklı bir } \\
\text { düşünce biçimi oluşturduğunu göstermektir. } \\
\text { Aktör ağ hesaplarını kaynakların, stratejilerin } \\
\text { ve stratejistlerin nasıl organize edildiği } \\
\text { göstermek için kullanabiliriz. }\end{array}$ \\
\hline $\begin{array}{l}\text { Power and the Perception of } \\
\text { Social Networks }\end{array}$ & $\begin{array}{l}\text { SIMPSON B. } \\
\text { MARKOVSKY B. } \\
\text { STEKETEE M. } \\
\text { Social Networks } \\
\text { May } 2011\end{array}$ & 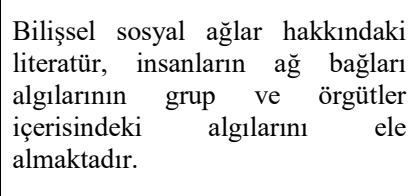 & $\begin{array}{l}\text { Eğer daha güçlü aktörler daha doğru algılara } \\
\text { sahiplerse, bu mevcut güç eşitsizliklerinin } \\
\text { muhafaza edildiği ya da çoğaltıldığ } 1 \text { bir araç } \\
\text { olacaktır. }\end{array}$ \\
\hline $\begin{array}{l}\text { Where Can Capabilities Come } \\
\text { from? Network Ties and } \\
\text { Capability Acquisition in } \\
\text { Business Groups }\end{array}$ & $\begin{array}{l}\text { MAHMOOD I.P. ZHU H. } \\
\text { ZAJAC E.J. } \\
\text { Strategic Management } \\
\text { August } 2011\end{array}$ & $\begin{array}{l}\text { İşletme grupları içerisinde ağ } \\
\text { bağları ve yetenek toplama. } \\
\text { İşletmelerin ağ bağlarının önemli } \\
\text { bir yetenek kazanımı kaynağın } \\
\text { nasıl olabildiği inceleniyor. }\end{array}$ & $\begin{array}{l}\text { Ağ yapılarının diğer yönlerinin işletme } \\
\text { gruplarındaki ağ yoğunluğunun, ağ bağlarının } \\
\text { Ar-Ge kabiliyeti üzerindeki etkinliğini nasıl } \\
\text { etkilediğine dair özgün bir analiz sunuluyor. } \\
\text { Ampirik olarak, firma yeteneklerini titizlikle } \\
\text { ölçmek için stokastik bir sinır tahminini } \\
\text { kullanarak yetenek literatürüne özgün bir } \\
\text { katkı sağlanıor. }\end{array}$ \\
\hline $\begin{array}{l}\text { A Framework for the Analysis of } \\
\text { Global, Regional and Local } \\
\text { Business Networks }\end{array}$ & $\begin{array}{l}\text { MANDJAK T. SIMON J. } \\
\text { SZALKAI Z. } \\
\text { Industrial Marketing } \\
\text { Management } \\
\text { August } 2011\end{array}$ & 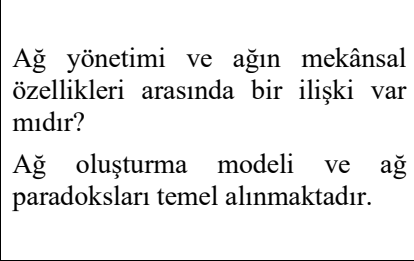 & $\begin{array}{l}\text { Ağ bir işletmenin ya da bireyin ağdaki tüm } \\
\text { etkileşimlerini kapsar. } \\
\text { Her ağ, ağdaki tüm katılımcılar için hem } \\
\text { bireysel hem de toplu olarak sürekli ağ } \\
\text { sonuçları üretir. } \\
\text { Ağların dinamik ve karmaşı özellikleri } \\
\text { dikkate alınmalıdır. }\end{array}$ \\
\hline $\begin{array}{l}\text { Organizations as Networks of } \\
\text { Communication Episodes: }\end{array}$ & $\begin{array}{l}\text { BLASCHKE S. } \\
\text { SCHOENEBORN D. }\end{array}$ & 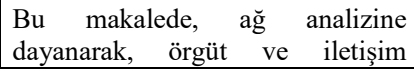 & $\begin{array}{l}\text { Son yıllarda, iletişimin örgütleri oluşturduğu } \\
\text { fikri, örgüt çalışmalarına önemli bir ivme }\end{array}$ \\
\hline
\end{tabular}


ÇUBUKCU, Murat - Örgütler Arası Ağların Stratejik Önemine Dair Literatürdeki Güncel Tartışmalar

\begin{tabular}{|c|c|c|c|}
\hline $\begin{array}{l}\text { Turning the Network Perspective } \\
\text { Inside Out }\end{array}$ & $\begin{array}{c}\text { SEIDL D. } \\
\text { Organization Studies } \\
2012\end{array}$ & $\begin{array}{l}\text { arasında ki ilişkinin araştırılmasına } \\
\text { yeni bir metodolojik yaklaşım } \\
\text { sunuyoruz. }\end{array}$ & $\begin{array}{l}\text { kazandırmıştır. } \\
\text { Örgütler arası ağ yaklaşımları gibi, örgüt içi } \\
\text { ağ yaklaşımları da dikkat çekmektedir. }\end{array}$ \\
\hline $\begin{array}{l}\text { How to Build a Strategic } \\
\text { Network: A Practitioner-Oriented } \\
\text { Process Model for the ICT Sector }\end{array}$ & $\begin{array}{l}\text { PARTANEN J. } \\
\text { MÖLLER K. } \\
\text { Industrial Marketing } \\
\text { Management } \\
\text { April } 2012\end{array}$ & $\begin{array}{l}\text { Ağlar, stratejik yönetim alanında } \\
\text { önemli bir alan oluşturur. } \\
\text { Stratejik bir ağın parçası olarak iş } \\
\text { yapma modeli oluşturmak. }\end{array}$ & $\begin{array}{l}\text { Stratejik bir ağın parçası olarak iş yapmak, } \\
\text { işletmelerin birbiriyle rekabet etmediklerini, } \\
\text { ancak diğer ağlarla rekabet ettiklerini ima } \\
\text { eder. } \\
\text { Gelecek için kritik başarı faktörü, stratejik } \\
\text { ağlar oluşturmak ve geliştirme yeteneğine } \\
\text { sahip olmaktır. }\end{array}$ \\
\hline $\begin{array}{l}\text { Network Structure and } \\
\text { Observational Learning: Evidence } \\
\text { from a Location-Based Social } \\
\text { Network }\end{array}$ & $\begin{array}{l}\text { SHI Z. WHINSTON A.B. } \\
\text { Journal of Management } \\
\text { Information Systems } \\
\text { Fall } 2013\end{array}$ & Ağ yapısı ve gözlemsel öğrenme & $\begin{array}{l}\text { Ağ içinde öğrenme sürecinin klasik öğrenme } \\
\text { modelinden ince ama önemli bir açıldan farklı } \\
\text { olduğunu öne sürüyoruz; arkadaşların } \\
\text { deneyimlerine önem verdiklerinden ağ } \\
\text { arkadaşlarından öğrenirler. }\end{array}$ \\
\hline $\begin{array}{l}\text { Domestic alliance network to } \\
\text { attract foreign partners: Evidence } \\
\text { from international joint ventures } \\
\text { in China }\end{array}$ & $\begin{array}{l}\text { SHI W., SUN S.L. } \\
\text { PINKHAM B.C., } \\
\text { PENG M.W. } \\
\text { Journal of International } \\
\text { Business Studies } \\
2014\end{array}$ & $\begin{array}{l}\text { Yabancı ortakları çekmek için } \\
\text { yerel ittifak ağları }\end{array}$ & $\begin{array}{l}\text { Yabancı işletmelerin, yerel bir ittifak ağı } \\
\text { içerisinde benzersiz ağ yapısal avantajlarını } \\
\text { yüksek olduğunu savunuyoruz. Yapısal } \\
\text { avantajları iki ağ konumu özelliği } \\
\text { merkeziyet ve aracilıktır. Yabanci yatırımcilar } \\
\text { stratejik bir ağ içerisine girdiklerinde hem } \\
\text { yerel bir ortağın yetenek özelliklerini hem de } \\
\text { ağlarından daha fazla faydalanabilecektir. }\end{array}$ \\
\hline $\begin{array}{l}\text { Towards Strategic Flexibility: } \\
\text { Social Networks, Climate and } \\
\text { Uncertainty }\end{array}$ & $\begin{array}{l}\text { PEREZ V.F. MONTES } \\
\text { F.J.L. MORALES V.J. } \\
\text { Industrial Management and } \\
\text { Data Systems } \\
2014\end{array}$ & $\begin{array}{l}\text { Sosyal ağların büyüklüğ̈̈ ve } \\
\text { bağlarını gücünün, stratejik } \\
\text { esneklik ve örgütsel iklim üzerinde } \\
\text { ki olumlu rolü. }\end{array}$ & $\begin{array}{l}\text { İșletmelerin CEO'larını sosyal ağları daha } \\
\text { büyük olduğunda daha yüksek düzeyde } \\
\text { stratejik esnekliğe rol açar. } \\
\text { Sosyal ağlar, işbirlikçi çalışmalara olanak } \\
\text { tanır. }\end{array}$ \\
\hline $\begin{array}{l}\text { Synergistic Effects of } \\
\text { Relationship Managers' Social } \\
\text { Networks on Sales Performance }\end{array}$ & $\begin{array}{l}\text { GONZALEZ G.R. CLARO } \\
\text { D.P. PALMATIER R.W. } \\
\text { Journal of Marketing } \\
\text { January } 2014\end{array}$ & $\begin{array}{l}\text { Makalede, ağlar arası ve örtüşen ağ } \\
\text { sinerjilerinin } \quad \text { performans } \\
\text { üzerindeki etkisini göstermektedir. }\end{array}$ & $\begin{array}{l}\text { Çapraz ağ sinerjisinin özel performans artırıc1 } \\
\text { etkileri, tek bir ağdan aracllı ve yoğunluk } \\
\text { etkilerinden daha büyüktür. }\end{array}$ \\
\hline $\begin{array}{l}\text { Inside The Black Box of The } \\
\text { Corporate Staff: Social Networks } \\
\text { and The Implementation Of } \\
\text { Corporate Strategy }\end{array}$ & $\begin{array}{l}\text { KLEINBAUM A.M. } \\
\text { STUART T.E. } \\
\text { Strategic Management } \\
\text { Journal } \\
\text { January } 2014\end{array}$ & $\begin{array}{l}\text { Sosyal ağlar, koordinasyonu teşvik } \\
\text { etmek için yararlı bir araçtır. }\end{array}$ & $\begin{array}{l}\text { Örgütlerin sosyal yapısına ilişkin araştırmalar, } \\
\text { strateji uygulamalarını incelenmesinden } \\
\text { daha önemli olduğu öne sürülmektedir. } \\
\text { A ̆g oluşumu ile ilgili geniş literatür, ağ } \\
\text { oluşumunun, uygun iletişim firsatlarına çok } \\
\text { fazla bağlı olduğunu göstermektedir. }\end{array}$ \\
\hline $\begin{array}{l}\text { Organizing Product Recovery in } \\
\text { Industrial Networks }\end{array}$ & $\begin{array}{l}\text { INSANIC I. GADDE L.E. } \\
\text { International Journal of } \\
\text { Physical Distribution \& } \\
\text { Logistics Management } \\
\text { February } 2014\end{array}$ & $\begin{array}{l}\text { Ürün iyileştirme ağlarının bütünsel } \\
\text { bir bakış açısıyla düzenlenmesini } \\
\text { araştırmak. }\end{array}$ & $\begin{array}{l}\text { Endüstriyel ağ teorisi, ticari gerçekliğin üç } \\
\text { boyutuna dayanan bir çerçeve sunar; } \\
\text { faaliyetler, kaynaklar ve aktörler. } \\
\text { Bir ağ, birbiriyle bağlantılı ilişki kümelerini } \\
\text { içerir. Bu da bir ilişkinin diğer ilişkilere } \\
\text { yerleştiğini ifade eder. }\end{array}$ \\
\hline $\begin{array}{l}\text { Reflections on Actor-Network } \\
\text { Theory, Governance Networks, } \\
\text { and Strategic Outcomes }\end{array}$ & $\begin{array}{l}\text { MONTENEGRO L.M. } \\
\text { BULGACOV S. } \\
\text { Brazilian Administration } \\
\text { Review } \\
\text { Jan.-Mar. } 2014\end{array}$ & $\begin{array}{l}\text { Bu makalede, yönetişim, aktör-ağ } \\
\text { teorisi ve stratejik sonuçlar ile } \\
\text { ilgili temalar odaklanılmıştır. }\end{array}$ & $\begin{array}{l}\text { İnsan ve insan dışı aktörlerin, aktör ağ kuramı } \\
\text { kapsamına alınmasını önererek yönetişim ağ } \\
\text { kuramı anlayışını genişletmeye çalıştık. } \\
\text { Ağlar, dâhil olan aktörlerin aktif katılımını } \\
\text { yani hareket ve süreç gerektirir. }\end{array}$ \\
\hline $\begin{array}{l}\text { Combining Structure, } \\
\text { Governance, and Context: A } \\
\text { Configurational Approach to } \\
\text { Network Effectivenes }\end{array}$ & $\begin{array}{l}\text { RAAB J. MANNAK R.S. } \\
\text { CAMBRE B. } \\
\text { Journal of Public } \\
\text { Administration Research } \\
\text { and Theory } \\
\text { April } 2015\end{array}$ & $\begin{array}{l}\text { A } \breve{g} \text { yapısının (ağ entegrasyonu) ve } \\
\text { içeriğinin (kaynak uyumu ve } \\
\text { istikrar) ağ yönetişim modunun ağ } \\
\text { etkinliği ile iliş̧isini araştırmaktır. }\end{array}$ & $\begin{array}{l}\text { Örgütler arası yatay ve hiyerarşik olmayan } \\
\text { iletişim ve iş birliği biçimleri toplumsal } \\
\text { sorunlara yeni ve kapsaml çözümler } \\
\text { arayışında daha yaygın hale gelmiştir. } \\
\text { Ağlar hiyerarşilerden daha esnek bir yönetim } \\
\text { biçimidir. }\end{array}$ \\
\hline $\begin{array}{l}\text { The Microstructures of Network } \\
\text { Recall: How Social Networks are } \\
\text { Encoded and Represented in } \\
\text { Human Memory }\end{array}$ & $\begin{array}{l}\text { BRASHEARS M.E. } \\
\text { QUINTANE E. } \\
\text { Social Networks } \\
\text { May } 2015\end{array}$ & $\begin{array}{l}\text { Bireysel tercihe dayalı kararlar, } \\
\text { ağın gerçek durumuna değil, } \\
\text { algilanan durumuna dayanacaktır. }\end{array}$ & $\begin{array}{l}\text { Giderek artan sayıda çalışmada, ă̆ yapısının } \\
\text { psikoloji ve bilişim yönlerinin nasıl alındığı } \\
\text { ve hafizada saklandığ ortaya konulmaktadır. }\end{array}$ \\
\hline $\begin{array}{c}\text { Formation of Strategic Networks } \\
\text { Under High Uncertainty of a } \\
\text { Megaproject }\end{array}$ & $\begin{array}{l}\text { JUSSILA A., MAINELA } \\
\text { T., NATTI S., } \\
\text { Journal of Business \& } \\
\text { Industrial Marketing } \\
2016\end{array}$ & $\begin{array}{l}\text { Yüksek belirsizlik projelerinde } \\
\text { stratejik ağlar nasıl oluşur? }\end{array}$ & $\begin{array}{l}\text { Stratejik ağlar, yani karşıllklı olarak yaratılan } \\
\text { ticari ağlar, karşılıklı değer yaratma mantığı } \\
\text { ve özel amaçlarla iş birliği yapar. Değer } \\
\text { sisteminde, stratejik ağların oluşturulmasının } \\
\text { önemli unsurları; güven ve bağımlılığın } \\
\text { gelişimidir. }\end{array}$ \\
\hline
\end{tabular}




\begin{tabular}{|c|c|c|c|}
\hline $\begin{array}{l}\text { Strategic Networks of Discovery } \\
\text { and Creation Entrepreneurs }\end{array}$ & $\begin{array}{l}\text { UPSON J. DAMARAJU N. } \\
\text { L., ANDERSON J. R., } \\
\text { BARNEY J.B., } \\
\text { European Management } \\
\text { Journal } \\
2017\end{array}$ & $\begin{array}{l}\text { Kâşif ve Yaratıcı Girişimci } \\
\text { Stratejik ağları. } \\
\text { Güncel araştırmalar, stratejik ağlar } \\
\text { içerisinde çeşitliliği, bir fikir } \\
\text { üretme ve firsat arayışı kaynağı } \\
\text { olarak desteklemektedir. }\end{array}$ & $\begin{array}{l}\text { Bu çalışma, girişimcilerin bazı yaratıcı } \\
\text { ortamlardaki yaratma ortamlarında, farkl } \\
\text { sosyal ağlardan girdi aradığını } \\
\text { göstermektedir. Bu tür ağlar, girişimcilerin } \\
\text { farklı bilgi kaynaklarına erişmelerine } \\
\text { yardımcı olabilirler. Ağların girişimcilik } \\
\text { üzerindeki etkileri üzerine yapılan } \\
\text { çalışmaların çoğu yapısal bir bakış açıs } \\
\text { benimsemiştir. }\end{array}$ \\
\hline $\begin{array}{l}\text { A Framework for Understanding } \\
\text { Strategic Network Performance: } \\
\text { Exploring Efficiency and } \\
\text { Effectiveness at the Network } \\
\text { Level }\end{array}$ & $\begin{array}{l}\text { BAYNE L., SCHEPIS D., } \\
\text { PURCHASE S., } \\
\text { Industrial Marketing } \\
\text { Management } \\
2017\end{array}$ & $\begin{array}{l}\text { Stratejik ağ performansını anlamak } \\
\text { için bir çerçeve. } \\
\text { Makale, ağ performansının nasıl } \\
\text { anlaşıldığını anlamak için teorik } \\
\text { bir çerçeve sunar. }\end{array}$ & $\begin{array}{l}\text { A } \breve{g} \text { performansını, ă̆ verimliliği ve etkinliği } \\
\text { ile uyumlu hale getirmek olarak anllyoruz. } \\
\text { Stratejik ağlarla özellikle ilgili olan kolektif } \\
\text { bir duyumsal modeli içeren, aktörler- } \\
\text { kaynaklar- faaliyetler modeli uygulanır. }\end{array}$ \\
\hline $\begin{array}{l}\text { Organizational Knowledge } \\
\text { Networks and Local Search: The } \\
\text { Role Of Intra-Organizational } \\
\text { Inventor Networks }\end{array}$ & $\begin{array}{l}\text { PARUCHURI S. } \\
\text { AWATE S. } \\
\text { Strategic Management } \\
\text { Journal } \\
\text { March } 2017\end{array}$ & $\begin{array}{l}\text { Örgüt bilgi ağları. } \\
\text { Bu makalede, örgüt içi ağlara ve } \\
\text { özelliklede örgüt içi ağlarda farklı } \\
\text { pozisyonları olan } \quad \text { bireylere } \\
\text { odaklanıyoruz. }\end{array}$ & $\begin{array}{l}\text { İşletmeler içerisinde büyük miktarlarda bilgi } \\
\text { bulunabilir. Yöneticiler bu bilgiyi kimin } \\
\text { kullanabileceğini anlamak için fikir } \\
\text { üretmeliler. Bilgi çalışanları arasında iş } \\
\text { birliğine odaklanıyoruz. }\end{array}$ \\
\hline $\begin{array}{l}\text { Understanding Business } \\
\text { Networks from a Mixed Network } \\
\text { and System Ontology Position }\end{array}$ & $\begin{array}{l}\text { PRENKERT F. } \\
\text { IMP Journal } \\
\text { June } 2017\end{array}$ & \begin{tabular}{lrr} 
Bu makalenin amacı, endüstriyel \\
ağların & karmaşı, & adaptif \\
ekonomik & sistemlerin ampirik \\
tezahürleri & \multicolumn{4}{c}{ olarak } \\
kavramsallaştırmak için ağ ve \\
sistem ontolojisini birleştirmenin \\
etkilerini vurgulamaktır.
\end{tabular} & $\begin{array}{l}\text { A ğ ontolojisi, sosyal mekanizmaların belirli } \\
\text { durumlarda tekrarlayan sonuçlara yol açan } \\
\text { aktörler, faaliyetler ve kaynaklar ağı olarak } \\
\text { kavramsallaştırıla bilineceği anlamına gelir. }\end{array}$ \\
\hline $\begin{array}{l}\text { Beyond Trust: Towards a } \\
\text { Practice-Based Understanding of } \\
\text { Governing Network } \\
\text { Organizations }\end{array}$ & $\begin{array}{l}\text { MIERSCH Y.T. } \\
\text { Journal of Management \& } \\
\text { Governance } \\
\text { June } 2017\end{array}$ & $\begin{array}{l}\text { Güvenin ötesinde: Yöneten ağ } \\
\text { örgütlerinden uygulamaya dayalı } \\
\text { bir anlayışa doğru }\end{array}$ & $\begin{array}{l}\text { A } \mathrm{g} \text { ve ağ örgütẗ kavramları, üretken } \\
\text { faaliyetlerin koordinasyonunu düşünmek, } \\
\text { anlamak ve kavramsallaştırmak için en } \\
\text { önemli kavramlardan biri olarak ortaya } \\
\text { çıkmaktadır. }\end{array}$ \\
\hline $\begin{array}{l}\text { Managing Business and } \\
\text { Innovation Networks-From } \\
\text { Strategic Nets to Business Felds } \\
\text { and Ecosystems }\end{array}$ & $\begin{array}{l}\text { MÖLLER K., } \\
\text { HALINEN A., } \\
\text { Industrial Marketing } \\
\text { Management } \\
\text { November } 2017\end{array}$ & \begin{tabular}{lr} 
A ğ yönetimi & \multicolumn{2}{c|}{ araştırmasında } \\
2000'den 2016'ya & kadar olan \\
disiplin aç1lımlarına & odaklanan \\
temel & değişmeler \\
değerlendirilmiştir. &
\end{tabular} & $\begin{array}{l}\text { Genel bir ağ yönetimi teorisi önerilmektedir. } \\
\text { İş amaçları ve hedeflerine ulaşmak için } \\
\text { oluşturulan stratejik ağlar veya değer ağları } \\
\text { olarak kasten tasarlanmış, iş ve yenilik } \\
\text { ağlarının oluşturulması ve yönetilmesidir. }\end{array}$ \\
\hline $\begin{array}{l}\text { Managing Strategic System- } \\
\text { Building Networks in Emerging } \\
\text { Business Felds: A Case Study of } \\
\text { the Dutch Smart Grid Sector }\end{array}$ & $\begin{array}{l}\text { PLANKO J. CHAPPIN } \\
\text { M.M. CRAMER J. M. } \\
\text { HEKKERT M.P. } \\
\text { Industrial Marketing } \\
\text { Management } \\
\text { November } 2017\end{array}$ & $\begin{array}{l}\text { Örgütler arası ağlarda, kurumsal iş } \\
\text { birliği, işletme yönetiminin baskın } \\
\text { bir biçimi haline gelmiştir. }\end{array}$ & $\begin{array}{l}\text { İşletmeler için kritik başarı faktörü, özellikle } \\
\text { hızlı bir şekilde değişen teknoloji yoğun } \\
\text { sektörlerde stratejik ağlar oluşturma ve } \\
\text { geliştirme yeteneğidir. }\end{array}$ \\
\hline $\begin{array}{l}\text { Network Orchestration for Value } \\
\text { Platform Development }\end{array}$ & $\begin{array}{c}\text { PERKS H. } \\
\text { KOWALKOWSKI C. } \\
\text { WITELL L. } \\
\text { GUSTAFSSON A. } \\
\text { Industrial Marketing } \\
\text { Management } \\
\text { November } 2017\end{array}$ & $\begin{array}{l}\text { Değer platformu geliştirmek için } \\
\text { ağ uyarlaması. }\end{array}$ & $\begin{array}{l}\text { Platformlar, aktörler ağıyla birlikte yaratılan } \\
\text { değer etrafinda giderek artmaktadır. Bu } \\
\text { ortamlarda, liderler ortamlarını şekillendirir } \\
\text { ve ağ uyarlamasıyla değer platformları } \\
\text { geliştirir. }\end{array}$ \\
\hline $\begin{array}{l}\text { Strategic Practices of Subsidiary } \\
\text { Positioning in Business Networks }\end{array}$ & $\begin{array}{l}\text { SALMELA S.L. } \\
\text { MAINELA T. PERNU E. } \\
\text { PUHAKKA V. } \\
\text { IMP Journal } \\
2018\end{array}$ & $\begin{array}{l}\text { Bu makalenin amacı, çok uluslu } \\
\text { işletmeler bağlamında dinamik iş } \\
\text { ağları içerisinde yer alan } \\
\text { konumlandırmayı incelemektir. }\end{array}$ & 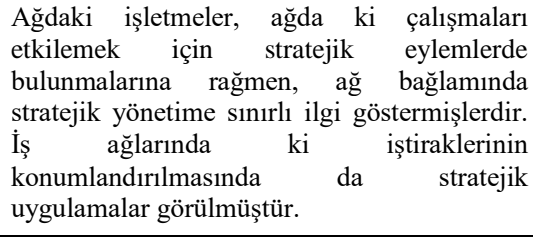 \\
\hline $\begin{array}{l}\text { Revisiting the Uppsala } \\
\text { Internationalization Model Social } \\
\text { Network Theory and Overcoming } \\
\text { the Liability of Outsidership }\end{array}$ & $\begin{array}{c}\text { YAMIN M. } \\
\text { KURT Y. } \\
\text { International Marketing } \\
\text { Review } \\
2018\end{array}$ & $\begin{array}{l}\text { İçerden öğrenen aktörlerin ağ } \\
\text { konumlarının piyasaya giriş } \\
\text { bazındaki etkisi } \\
\text { açışısından rolünü } \\
\text { aralmaktadır. }\end{array}$ & $\begin{array}{l}\text { Literatürde, uluslararasılaşma sürecinde ağ } \\
\text { bağlantılarının öneminin altı çizilmiştir. } \\
\text { Açı ağlardaki aktörler, iş birliği } \\
\text { stratejilerinde daha fazla esnekliğe sahiptir. }\end{array}$ \\
\hline $\begin{array}{l}\text { Strategic Networks and New } \\
\text { Product Performance: The } \\
\text { Mediating Role of Ambidextrous } \\
\text { Innovation }\end{array}$ & $\begin{array}{c}\text { XIE X. } \\
\text { GAO Y. } \\
\text { Technology Analysis \& } \\
\text { Strategic Management }\end{array}$ & $\begin{array}{l}\text { Stratejik ağlar, yeni ürün } \\
\text { performansı ve yenilik. } \\
\text { Stratejik ağlar, işletmelerin a a } \\
\text { dışındaki rakiplerine karşı rekabet } \\
\text { avantaj1 elde etmelerine olanak }\end{array}$ & $\begin{array}{l}\text { Bir kaynak olarak stratejik ağlar, işletmelerin } \\
\text { bilgi yönetim yeteneklerini } \\
\text { geliştirebilmelerine ve yeni ürünlerin } \\
\text { gelişimini teşvik etmelerine ve böylelikle } \\
\text { inovasyon sonuçlarını kolaylaştırabilmelerine }\end{array}$ \\
\hline
\end{tabular}


ÇUBUKCU, Murat - Örgütler Arası Ağların Stratejik Önemine Dair Literatürdeki Güncel Tartışmalar

\begin{tabular}{|c|c|c|c|}
\hline & 2018 & $\begin{array}{l}\text { tanıyan, uzun vadeli amaca yönelik } \\
\text { düzenlemelerdir. }\end{array}$ & $\begin{array}{lcc}\text { yardımc1 olabilir. } & \text { Stratejik ağlar, } \\
\text { sürdürülebilirlik ve inovasyon konusunda } \\
\text { önemli rol oynar. }\end{array}$ \\
\hline $\begin{array}{l}\text { Strategy Implementation and } \\
\text { Organizational Change: How } \\
\text { Formal Reorganization Affects } \\
\text { Professional Networks }\end{array}$ & $\begin{array}{l}\text { LYNCH S.E. MORS M.L. } \\
\text { Long Range Planning } \\
\text { February } 2018\end{array}$ & $\begin{array}{l}\text { Strateji uygulaması ve örgütsel } \\
\text { değişim, profesyonel ağları nasıl } \\
\text { etkiler? }\end{array}$ & $\begin{array}{l}\text { Özellikle sosyal yapıya yüksek oranda } \\
\text { yerleşik olan ağ bağlarının, biçimsel yapıdaki } \\
\text { değişikliklerden etkilenme olasilığ daha } \\
\text { azdır. }\end{array}$ \\
\hline Network Synergy & $\begin{array}{l}\text { HERNANDEZ E. } \\
\text { SHAVER M.J. } \\
\text { Administrative Science } \\
\text { Quarterly } \\
\text { February } 2018\end{array}$ & $\begin{array}{l}\text { Bir işletmenin bir örgütler arası } \\
\text { ağdaki konumu, çeşitli performans } \\
\text { sonuçlarını etkiler. Bu nedenle } \\
\text { işletmelerin } \quad \text { değerli r yapısal } \\
\text { pozisyonları nasıl elde ettiği } \\
\text { önemli bir araştırma sorusu haline } \\
\text { gelmiştir. }\end{array}$ & $\begin{array}{l}\text { İşletmeler ağlarını değiştirebilir ve çok farklı } \\
\text { bir mekanizma olan satın alma yoluyla değerli } \\
\text { yapısal pozisyonlar elde edebilirler. } \\
\text { İşletmeler sadece pazarda rekabet edebilecek } \\
\text { kaynaklar elde etmek için ağları } \\
\text { kullanmayabilir, aynı zamanda süreç } \\
\text { içerisinde ağ konumu için rekabet edebilirler. }\end{array}$ \\
\hline $\begin{array}{l}\text { Top Persuader Prediction For } \\
\text { Social Networks }\end{array}$ & $\begin{array}{l}\text { FANG X. } \\
\text { HU P.J.H. } \\
\text { MIS Quarterly } \\
\text { March } 2018\end{array}$ & $\begin{array}{l}\text { Bir sosyal ağ, bir dizi sosyal } \\
\text { varlıktan ve bunlar arasındaki } \\
\text { ilişkilerden oluşur. } \\
\text { Sosyal ağlar içindeki en önemli } \\
\text { olgu, sosyal iknadır. }\end{array}$ & $\begin{array}{l}\text { Sosyal bir kurumun, sosyal bir ağdaki tutum, } \\
\text { inanç ve darranışını diğer varlıkları } \\
\text { etkilediği ilke süreçler, sosyal iknayı ifade } \\
\text { eder. İnsanlar, onlarla yakın ilişkide oldukları } \\
\text { kimselere benzeme eğilimi gösterirler. }\end{array}$ \\
\hline $\begin{array}{l}\text { From Social Network to Firm } \\
\text { Performance }\end{array}$ & $\begin{array}{c}\text { PRATONO A.H. } \\
\text { Management Research } \\
\text { Review } \\
\text { April } 2018\end{array}$ & $\begin{array}{l}\text { Bu çalışmanın amacı, sosyal ağ ve } \\
\text { yönetim performansı arasındaki } \\
\text { karmaşı ilişkiyi açıklamak. }\end{array}$ & $\begin{array}{l}\text { Bu makale, sosyal ağ ve sosyal performans } \\
\text { arasındaki karmaşı ilişkide güven aracının } \\
\text { rolünü açıklayarak sosyal sermaye teorisine } \\
\text { katkıda bulunmaktadır. }\end{array}$ \\
\hline $\begin{array}{c}\text { Change in Business Relationships } \\
\text { and Networks: Concepts and } \\
\text { Business Reality }\end{array}$ & $\begin{array}{l}\text { FONFARA K. MROZEK } \\
\text { M.R. GRZEGORZ L. } \\
\text { Industrial Marketing } \\
\text { Management } \\
\text { April } 2018\end{array}$ & İş ilişkilerinde ve Ağlarda Değişim & $\begin{array}{l}\text { Bir işletmedeki değişiklik kendisi ile ilişkilere } \\
\text { sahip kuruluşlar ve daha geniş bir iş ağı için } \\
\text { geniş sonuçlar doğurabilir. }\end{array}$ \\
\hline $\begin{array}{l}\text { How Do Network Resources } \\
\text { Affect Firms' Network-Oriented } \\
\text { Dynamic Capabilities? }\end{array}$ & $\begin{array}{l}\text { ALINAGHIAN L. } \\
\text { RAZMDOOST K. } \\
\text { Industrial Marketing } \\
\text { Management } \\
\text { May } 2018\end{array}$ & $\begin{array}{l}\text { A } \breve{g} \text { kaynakları, a a } \text { yönelimli } \\
\text { dinamik yeteneklerini nasıl etkiler? }\end{array}$ & $\begin{array}{l}\text { İșletmeler, ağ kaynaklarının yaratılmasılyla } \\
\text { ilgili değerlerin belirlenmesi, oluşturulması ve } \\
\text { daha da geliştirilmesi için ağ aktörleriyle } \\
\text { bağlantı kurmalıdır. }\end{array}$ \\
\hline $\begin{array}{l}\text { The Balanced Scorecard Logic in } \\
\text { the Management Control and } \\
\text { Reporting of Small Business } \\
\text { Company Networks: A Case } \\
\text { Study }\end{array}$ & $\begin{array}{l}\text { AURELI S., CORDONI A. } \\
\text { BALDO M.D., } \\
\text { LOMBARDI R. } \\
\text { Accounting and } \\
\text { Management Information } \\
\text { Systems } \\
\text { June } 2018\end{array}$ & $\begin{array}{l}\text { Bu makalenin amacı, denge puan } \\
\text { kartı mantığının uygulanmasını, } \\
\text { işlevlerini tanımlayan iş ağlarını } \\
\text { değerlendirmek ve entegre etmek } \\
\text { için kullanmaktır. }\end{array}$ & $\begin{array}{l}\text { Dengeli puan kartı, işletme ağları alanında } \\
\text { etkili bir yönetim aracı haline getirmektedir. } \\
\text { Ağ yöneticisine geçerli bir destek sağlayabilir. }\end{array}$ \\
\hline $\begin{array}{c}\text { Management and Organization } \\
\text { Review }\end{array}$ & $\begin{array}{c}\text { ZHAO C. } \\
\text { BURT R.S. } \\
\text { A Note on Business Survival } \\
\text { and Social Network } \\
\text { June } 2018\end{array}$ & $\begin{array}{l}\text { İş̧ hayatında hayatta kalma ve } \\
\text { sosyal ağlar üzerine notlar. }\end{array}$ & $\begin{array}{l}\text { A ğ avantajı zayıflığı telafi etmez, kümülatif } \\
\text { avantaj için bir mekanizmadır, zaten iyi olan } \\
\text { işletmelerin başarısını artırır. } \\
\text { Literatürde işletmelerin sonrakim başarıları } \\
\text { için ilk ağ etkinliklerinin önemine dikkat } \\
\text { çekilmiştir. }\end{array}$ \\
\hline $\begin{array}{c}\text { Building a Social Network for } \\
\text { Success }\end{array}$ & $\begin{array}{l}\text { ANSARI A. STAHL F. } \\
\text { HEITMANN M. } \\
\text { BREMER L. } \\
\text { Journal of Marketing } \\
\text { Research } \\
\text { June } 2018\end{array}$ & $\begin{array}{l}\text { Başarı için bir sosyal ağ oluşturma. } \\
\text { Başarıyı yönlendirmek için, sosyal } \\
\text { ağ varlığını nasıl yönetmeliyiz? }\end{array}$ & $\begin{array}{l}\text { Yapıllan çalışmalara göre, ağlardan elde edilen } \\
\text { veriler kullanılarak, sosyal ağ varlığını ve } \\
\text { ilişkilerini güçlendirebiliriz. } \\
\text { Sosyal a a literatürü, işletme eylemlerinin } \\
\text { etkinliğinin, ağ yoğunluğuna bağlı } \\
\text { olabileceğini düşündürmektedir. }\end{array}$ \\
\hline $\begin{array}{l}\text { More or Less Guanxi: Trust is } \\
60 \% \text { Network Context, } 10 \% \\
\text { Individual Difference }\end{array}$ & $\begin{array}{l}\text { BURT R.S. } \\
\text { BIAN Y. } \\
\text { OPPER S. } \\
\text { Social Networks } \\
\text { July } 2018\end{array}$ & $\begin{array}{l}\text { Güven ve sosyal ağ arasındaki } \\
\text { bağlantı, özellikle iş ve politik } \\
\text { farklılıklar olmak üzere bireyler } \\
\text { arasındaki çoğu farklılığa karşı } \\
\text { güçlüdür. }\end{array}$ & $\begin{array}{l}\text { Güven varyansı \%60 ağ içerir, \%10 bireysel } \\
\text { farklılıklar. } \\
\text { Bağlantının etrafinda ağ kapanması arttıkça } \\
\text { güven artmaktadır. } \\
\text { Sosyal sermaye, kapalı ağların güvenini } \\
\text { kolaylaştırır. }\end{array}$ \\
\hline $\begin{array}{l}\text { Resource congestion in alliance } \\
\text { networks: How a firm's partners' } \\
\text { partners influence the benefits of } \\
\text { collaboration }\end{array}$ & $\begin{array}{c}\text { Vikas A. } \\
\text { Strategic Management } \\
\text { Journal } \\
\text { December } 2019\end{array}$ & $\begin{array}{l}\text { Stratejik ittifaklar, bilgi yoğun } \\
\text { ortamlarda yöneticiler için önemli } \\
\text { bir araçtır: Firmaları, inovasyon } \\
\text { sürecine girdi olarak kritik öneme } \\
\text { sahip olabilecek çeşitli bilgilere ve } \\
\text { know-how'a erişmelerine izin } \\
\text { verir. }\end{array}$ & $\begin{array}{l}\text { Bir firmanın stratejik ittifakları aracılığıyla } \\
\text { erişebileceği ağ kaynakları, yeniliğin kritik } \\
\text { öncüleridir ve yeni bilgi üretmek için gerekli } \\
\text { olan bilgiyi sağlar. Literatür, ağ kaynaklarının } \\
\text { kapasiteleri üzerindeki kisıtlamalardan } \\
\text { kaynaklanan tıkanıklığını doğrudan dikkate } \\
\text { almamıştır. Bu gibi durumlarda yöneticilerin }\end{array}$ \\
\hline
\end{tabular}




\begin{tabular}{|c|c|c|c|}
\hline & & & $\begin{array}{l}\text { gözden kaçırabileceği şey, ittifak ortaklarının } \\
\text { bilgi temelli kaynaklarının, ortaklarının dahil } \\
\text { olduğu diğer ittifaklardan gelen bu kaynaklar } \\
\text { üzerindeki rekabet eden iddialar nedeniyle } \\
\text { tıkanabileceğidir. }\end{array}$ \\
\hline $\begin{array}{l}\text { A model for dynamic alliance } \\
\text { networks }\end{array}$ & $\begin{array}{c}\text { ABDUSSALAM A. } \\
\text { HAWRYSZKIEWYCZ I. } \\
\text { The Journal of Corporate } \\
\text { Transformation } \\
\text { May } 2020\end{array}$ & 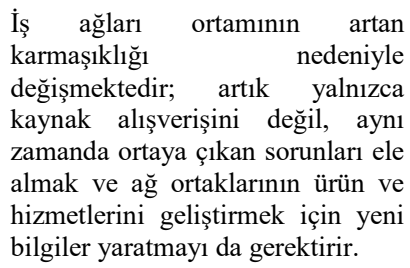 & $\begin{array}{l}\text { İş ağları, genellikle üyelik değişikliği ve } \\
\text { üyelerin yaptıklarıyla iş ortamındaki } \\
\text { değişikliklere sürekli olarak uyum sağlamaları } \\
\text { gerektiğinden, doğası gereği giderek daha } \\
\text { dinamik hale geliyor. Iş ağı kurmak isteyen } \\
\text { işletmeler bunu bu özelliklerde tanımlayabilir } \\
\text { ve bilgisayar destek sistemine dönüştürebilir. }\end{array}$ \\
\hline $\begin{array}{l}\text { Network Together: Node } \\
\text { Classification via Cross-Network } \\
\text { Deep Network Embedding }\end{array}$ & $\begin{array}{c}\text { Xiao S., DAI Q. } \\
\text { MAO S., CHUNG F.L. } \\
\text { CHOI K.S. } \\
\text { Transactions on Neural } \\
\text { Networks and Learning } \\
\text { Systems } \\
\text { May } 2021\end{array}$ & $\begin{array}{l}\text { Bu makalede, bir hedef ağdaki } \\
\text { düğümleri sinıflandırmaya } \\
\text { yardımcı olmak için bir kaynak } \\
\text { ağdan bol miktarda bulunan } \\
\text { bilgiden yararlanmayı amaçlayan } \\
\text { bir ağlar arası düğüm sınıflandırma } \\
\text { problemini inceliyoruz }\end{array}$ & $\begin{array}{l}\text { Daha güçlü bağlı düğümleri daha benzer gizli } \\
\text { vektör temsillerine sahip olacak şekilde } \\
\text { eşleyerek, bir ağ içindeki düğümler arasındaki } \\
\text { yakınlıkları yakalamak için ağ yapılarından } \\
\text { yararlanılır. }\end{array}$ \\
\hline $\begin{array}{l}\text { Firm's Network Position and } \\
\text { Business Performance }\end{array}$ & $\begin{array}{l}\text { FONFARA K. MALYS L. } \\
\text { MROZEK M.R. } \\
\text { Gospodarka Narodowa } \\
\text { June } 2021\end{array}$ & $\begin{array}{l}\text { Bu makalenin amacı, firmanın } \\
\text { performansı bağlamında firmanın } \\
\text { iş ağındaki konumunun gelişimini } \\
\text { analiz etmek için bir çerçeve } \\
\text { önermektir. }\end{array}$ & $\begin{array}{l}\text { Bir işletmenin ağ } \\
\text { belirleyicilerindeki sürekli değişiklikler ve ağ } \\
\text { konumunu geliştirirken } \\
\text { davranışındaki sürekli değişiklikler nedeniyle } \\
\text { bir firmanın ağ konumunun sürekli değiştiğini } \\
\text { ileri sürmektedir. Buna karşı ağ } \\
\text { konumundaki değişiklikler firmanın } \\
\text { performansını etkiler. }\end{array}$ \\
\hline $\begin{array}{l}\text { The town of bent necks: } \\
\text { interorganizational causes and } \\
\text { consequences of relational rivalry }\end{array}$ & $\begin{array}{c}\text { SÖZEN H.C. } \\
\text { Journal of Strategy and } \\
\text { Management } \\
\text { June } 2021\end{array}$ & $\begin{array}{l}\text { Bu çalışma, ilişkisel ve ilişkisel } \\
\text { olmayan rekabetçi etkileşimlere } \\
\text { sahip firmaların ağ oluşturma } \\
\text { davranışları için kavramsal bir } \\
\text { çerçeve geliştirmeyi } \\
\text { amaçlamaktadır. Olumsuz bağların } \\
\text { rakip firmalar için rekabetin } \\
\text { anlamını nasıl değiştirdiği } \\
\text { tartışıldı. }\end{array}$ & $\begin{array}{l}\text { Örgütler arası ağlar üzerine yapılan } \\
\text { çalışmaların çoğu, çoğunlukla pozitif bağ } \\
\text { oluşum kalıpları ve bu etkileşimlerin } \\
\text { sonuçları ile ilgilidir. Ancak, olumsuz } \\
\text { firmalar arası ilişkilerin açılayıc1 } \\
\text { potansiyelini gerçekleştiren makro düzeydeki } \\
\text { çalışmalar sınırlı sayıdadır. Olumsuz örgütler } \\
\text { arası ilişkiler de ekonomik sosyoloji } \\
\text { disiplinine önemli katkılar sağlayabilir. }\end{array}$ \\
\hline
\end{tabular}

Kaynak: Yazar tarafından hazırlanmıştır.

Tablo 1'de görüldüğü gibi, uluslararası literatürdeki örgütler arası ağların önemine dair tartışmalarda; sosyal ağ yaklaşımlarının kökenleri, anahtar kavramlar ve yöntemlerinin tanıtıldığı, ağların ayırt edilebilir özelliklerinin, enformel ağların ve ağ ilişkilerinde güven meselesinin ve stratejik ittifaklarda bir sosyal ağ perspektifinin öneminin ve ağların sosyal yönlerinin de dikkate alınması gerektiğinin vurgulandığı, örgütler arası ağlarda sosyal yap1 ve rekabetin ekonomik hayatı nasıl etkilediğinin ve ağ oluşturmaya artan ilginin nedenlerinin tartış1lığı tespit edilmiştir.

Örgütler arası ağlar üzerine yapılan çalışmaların çoğunda, pozitif bağlar oluşturmanın ve bu etkileşimlerin olumlu sonuçlarının olduğu ve krizlere cevap vermede enformel ağların daha etkili olduğu öne sürülmektedir. Tablo 1'e yer alan bazı araştırmalarda ise; işletmelerin yabancı ağlardaki ilişkileri yoluyla uluslararasılaştıkları ve yerleşik oldukları ilişki ağlarının davranışlarını ve performanslarını derinden etkilemekte olduğu ve ağların işletmelere çeşitli faydalar sağlamak için yaygın olarak kullanıldıkları iddia edilmektedir. Ağda bilgi yaratma ve aktarma potansiyelinin önemine dikkat çekilmekte ve ağ bağlamındaki etkileşimlerin hem eylemleri k1sıtlayabileceği hem de etkinleştirebileceği öne sürülmektedir.

Yapılan araştırmalarda görüldüğü gibi, gelecekte ağların sayısının ve karmaşıklığının büyümesinin beklenildiği öngörülmektedir. Stratejik ağlar bir organizasyon tarzı olarak görülmektedir. Stratejik ağlar oluşturma ve geliştirme yeteneğinin gelecek için kritik bir başarı faktörü olarak görüldüğü ve ağların işbirlikçi çalışmalara olanak sağladığı ve sinerji yaratabileceği iddia edilmektedir.

\section{AĞLARA İLIŞKİN YEREL LITERATÜRDEKİ GÜNCEL TARTIŞMALAR}

Örgütlerin yerleşik olduğu ağlar, davranışları ve performanslarını derinden etkilemekte ve stratejik hedeflerine ulaşmalarına izin verebilmektedir. Örgütler arası ekonomik ilişkilerin ağdaki sosyal ilişkiler içinde gömülü olduğu bilinmektedir (Özkan Canbolat ve Çeliksoy, 2015:13). Özen ve Aslan (2006), Türkiye'de bireylerin kendi gruplanı dışındaki kişilere güvenemediklerini vurgulamaktadırlar. Türkiye'de yerleşiklik ilişkilerinin 
akrabalık ya da hemşehrilik yoluyla olmadığını taraflar arasındaki piyasa ilişkilerinin zaman içerisinde yerleşik hale geldiğine yönelik bulgular elde etmişlerdir (Özen ve Aslan, 2006:140-141).

Hofstede (1980), gibi araştırmalara göre Türk kültürü ortaklaşa davranışçı bir kültürdür. Türk kültürünün kolektivist doğası, zayıf bağlardan ziyade güçlü bağlar kullanarak iş büyümesini sağlamak için sosyal ilişkilere taşınır (Kozan ve Akdeniz, 2014:44). Türkiye'de örgütler arası ilişkilerin mevcut durumu, devlete bağımlılığın ağ ilişkileri üzerindeki etkisini vurgulayan Whitley'in (2000) ulusal iş sistemleri yaklaşımı ve Granovetter'in (1978) ve Coleman'ın (1988), Burt (1992) ve Podolny (2001) yerleşiklik tartı̧̧maları çerçevesinde ele alındığında, ülke ekonomisini yönlendiren dinamiklerin açıklanmasına yardımcı olabilecek bir model üretilebilir. Örgütlerin ağ ilişkilerinin yönünü belirleyebilecek, devletin piyasalarda üstlendiği role vurgu yapan ulusal iş sistemleri (Whitley, 1992) yaklaşımından faydalanılmıştır (Sargut vd., 2007:27-28).

Yapılan ulusal literatür taraması sonucunda, sosyal ağ ve sosyal sermaye üzerine yüksek lisans ve doktora tezleri olarak; Sözen (2007), Özdemir (2008), Erbil (2008), Özkan Canbolat (2008), Köker (2008), Demir (2009), Tuzlukaya (2013), Akyazı (2014) gibi akademisyenler tarafından yazılmış tezler olduğu tespit edilmiştir. Özgen, Kılıç ve Karademir (2003), Döğerlioğlu (2005), Karagül ve Masca (2005), Özen ve Aslan (2006), Sargut (2006), Öztaş (2007), Sözen ve Sargut (2008), Kapu (2008), Sözen ve Sağsan (2009), Kirkbeşoğlu ve Sözen (2009), Meydan (2010), Sözen ve Esatoğlu (2010), Sözen (2011), Tuzlukaya, Sargut ve Sözen (2014), Sargut ve Sözen (2014), Alan ve Sözen (2017), Ensari ve Karabağ (2017), Tunçay ve Özer (2017), Karakayacı ve Dinçer (2018) gibi akademisyenler tarafından sosyal sermaye ve ağ üzerine yazılmış ulusal makalelere de yer verilmiştir. Ayrıca, sosyal ağlar konusunda yapılan uluslararası yazın taramasında Sözen'in (2012) uluslararası dergide yayınlanmış makalesine rastlanmıştır. Tablo 2'de ağ konusunda Türkiye'de yazılmış 27 akademik çalışmanın başlı̆̆ı, yazarları, temel soru ve bulguları kronolojik olarak sıralanmış ve yeni araştırmacılara katkı sağlamak için özetlenmiştir.

Tablo 2. Ăg Konusunda Türkiye’de Yazılmış Bazı Akademik Çalışmaların Temel Soru ve Bulguları

\begin{tabular}{|c|c|c|c|}
\hline Araştırma Başlığı & $\begin{array}{c}\text { Araştırmayı Yapan } \\
\text { ve Tarihi }\end{array}$ & Temel Soruları & Temel Bulguları \\
\hline $\begin{array}{c}\text { Bağlam Kapsamında Örgütler Arası } \\
\text { Ağ Düzenekleri: Dayanıklı Ev } \\
\text { Aletleri Sektörü Örneği }\end{array}$ & $\begin{array}{l}\text { CENK H.S. } \\
\text { Dr. Tezi } \\
2007\end{array}$ & $\begin{array}{l}\text { - Literatürde yerleşiklik tartışmaları ve } \\
\text { sosyal yerleşiklik iddiası örgüt } \\
\text { araştırmalarında } \\
\text { değerlendirilmektedir? } \\
\text { - Örgütler ne tür ağ ilişkileri kurarlar ve } \\
\text { ağ içerisinde nasıl konumlandırılırlar? } \\
\text { - Belirli bir yapı içerisinde örgütler için } \\
\text { fayda sağlayan ilişkilerin niteliğinin } \\
\text { nedir? }\end{array}$ & $\begin{array}{l}\text { - A } \text { dü düzenekleri içerisindeki } \\
\text { aracıların güçlü olması dış aracılık } \\
\text { oranının yüksek olmasını sağlar. } \\
\text { - Örgütlerin ağ ilişkileri ve aracılık } \\
\text { faaliyetleri bağlamsal koşullarına } \\
\text { göre farklılık gösterebilmektedir. } \\
\text { - Örgütler kendilerine fayda } \\
\text { sağlayabilecek ağ ilişkileri } \\
\text { oluşturma eğilimindedirler. }\end{array}$ \\
\hline $\begin{array}{l}\text { Örgütsel Ağ Düzeneğinin Örgütsel } \\
\text { Alandaki Çeşitlilik ve Değişime } \\
\text { Etkisi: Çankırı Örneği }\end{array}$ & $\begin{array}{l}\text { CANBOLAT E.Ö. } \\
\text { Dr. Tezi } \\
2008\end{array}$ & $\begin{array}{l}\text { - Örgütsel çeşitliliğin örgütsel ağ } \\
\text { düzeneği yapısı üzerinde ne tür etkileri } \\
\text { vardır? } \\
\text { - Örgütsel alanda birbirlerinin } \\
\text { yapılarını, stratejilerini ve kültürlerini } \\
\text { taklit eden örgütlerden bazıları } \\
\text { diğerlerine göre örgütsel alanı } \\
\text { etkileme açısından ve örgütsel } \\
\text { değişime katkıları açısından daha } \\
\text { baskın rollere mi sahiptirler? }\end{array}$ & $\begin{array}{l}\text { - Ağ düzeneğindeki ilişki özellikleri ile } \\
\text { yenilik süreçleri arasında anlamlı bir } \\
\text { ilişki bulunmuştur. } \\
\text { - Politik güce sahip ve merkezde yer } \\
\text { alan örgütler yeniliklere daha hızlı } \\
\text { uyum sağlarlar. } \\
\text { - Hem güçlü bağlara hemde siyasi } \\
\text { güce sahip örgütler, diğer örgütlere } \\
\text { saha az benzerler. } \\
\text { - Baskılar olmadığında Güçlü bağlara } \\
\text { sahip örgütler, diğer örgütlere } \\
\text { benzemekte ve yenilikleri daha önce } \\
\text { benimserler. }\end{array}$ \\
\hline $\begin{array}{c}\text { Örgütler Arası Ağların Yenilik } \\
\text { Derecesi Üzerindeki Etkileri: } \\
\text { Ostim ve Ankara Organize Sanayi } \\
\text { Bölgelerinde Bir Çalışma }\end{array}$ & $\begin{array}{l}\text { KÖKER A.R. } \\
\text { Dr. Tezi } \\
2008\end{array}$ & $\begin{array}{l}\text { - Ürünlerin yenilik derecesi üzerinde ağ } \\
\text { içindeki konumunun, ağ } \\
\text { düzeneğindeki ilişki yapılarının } \\
\text { niteliğinin ve türünün etkisi nedir? }\end{array}$ & $\begin{array}{l}\text { - Ağlar içerisinde örgütlerin hayatta } \\
\text { kalma sürelerinin daha uzun olduğu } \\
\text { tespit edilmiştir. } \\
\text { - Örgütlerin yenilik derecesi üzerinde } \\
\text { yapısal boşlukları birleştirmenin } \\
\text { olumlu etkiye sahip olduğu } \\
\text { görülmektedir. } \\
\text { - Yenilikçi strateji benimseyen } \\
\text { örgütlerde bilgi transferi daha iyi } \\
\text { kullanıla bilinmektedir. }\end{array}$ \\
\hline
\end{tabular}




\begin{tabular}{|c|c|c|c|}
\hline $\begin{array}{l}\text { Kuşaklararası Değişimin Örgütlerarası } \\
\text { Ağdüzenekleri Yapılanmasına Etkisi }\end{array}$ & $\begin{array}{l}\text { TUZLUKAYA Ş.E. } \\
\text { Dr. Tezi } \\
2013\end{array}$ & $\begin{array}{l}\text { - Çalışmada, genelde yazında durağan } \\
\text { ele alınan ağ düzeneği yapılanması, } \\
\text { değişim üzerinden incelenmiştir. } \\
\text { - Örgütlerde kuşaklararası değişimler ile } \\
\text { örgütler arası ağ düzeneği } \\
\text { yapılanmalarının niteliklerinin } \\
\text { değişimi arasındaki ilişki ne yöndedir? } \\
\text { - Daha bütünsel şekilleri bireysel } \\
\text { seçimler nasıl meydana getirir? }\end{array}$ & $\begin{array}{l}\text { - Örgütlerin yeni ilişki kurmaları yeni } \\
\text { kaynaklara ulaşabilmelerini } \\
\text { kolaylaştırırmaktadır. } \\
\text { - Örgütler arası ilişkilerin yerleşikliği } \\
\text { esnekliği sınırlar. Karşlıklı etkileşim } \\
\text { ve ilişkiler rutinleştiğinde değişiklik } \\
\text { yapmak zorlaşmaktadır. } \\
\text { - Örgütlerarası güçlü bağların oranı } \\
\text { kuşaklararası deģişimle, azalmakta ve } \\
\text { buna karşın aracı aktörlerin oranı ise } \\
\text { artmaktadır. }\end{array}$ \\
\hline $\begin{array}{l}\text { Girişimcilik Sürecinde Sosyal } \\
\text { Sermaye ve Sosyal Ağlar İle İç } \\
\text { Girişimcilik Üzerine Bir Araştırma }\end{array}$ & $\begin{array}{l}\text { AKYAZI T.E. } \\
\text { Y.L. Tezi } \\
\quad 2014\end{array}$ & $\begin{array}{l}\text { - İşletmelerin sosyal sermaye ve iç } \\
\text { girişimcilik } \\
\text { belirlenmesinde sosyal düzeylerinin } \\
\text { sosyal ağ ö özelliklerinin } \\
\text { girişimcilikle iliş̧sisi ne yöndedir? }\end{array}$ & $\begin{array}{l}\text { - Girişimcilerin etki alanları geçmişte } \\
\text { yerel çevreleri ile sinırlı kalmakta } \\
\text { iken, küreselleşme ve iletişim } \\
\text { kolaylıkları sayesinde ağları aracılığı } \\
\text { ile daha geniş alanı etkiler hale } \\
\text { gelmiştir. } \\
\text { - İş insanlarının sosyal ağları } \\
\text { girişimcilik } \\
\text { performanslarını } \\
\text { etkilemektedir. } \\
\text { - Girişimciler, kurdukları işletmelerin } \\
\text { devamlılığını sağlayabilmek için, } \\
\text { sosyal sermayelerini de geliştirmek } \\
\text { zorundadırlar. } \\
\text { - Sosyal sermayenin kurumsal güven } \\
\text { boyutu ile iç girişimcilik ve sosyal } \\
\text { ağlar arasında bir ilişki bulunduğu } \\
\text { sonucuna ulaşılmıştır }\end{array}$ \\
\hline $\begin{array}{l}\text { Birlikten Kuvvet Doğar: Küçük ve } \\
\text { Orta Ölçekli İsletmeler İ̧in Bir } \\
\text { Örgütlenme Modeli Olarak A } \\
\text { Organizasyonları Önerisi }\end{array}$ & $\begin{array}{l}\text { ÖZGEN H. } \\
\text { KILIÇ K.C. } \\
\text { KARADEMİR B. } \\
\text { Makale } \\
2003\end{array}$ & $\begin{array}{l}\text { - Küçük ölçekli işletmeler stratejik iş } \\
\text { birlikleri yoluyla büyük olmanın } \\
\text { avantajlarını da kullanabilirler mi? }\end{array}$ & 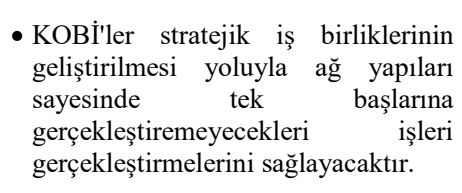 \\
\hline $\begin{array}{l}\text { Sosyal Ağlar ve Örgütsel Başarı: } \\
\text { Yerleşiklik Teorisi }\end{array}$ & $\begin{array}{l}\text { DÖĞERLİOĞLU Ö. } \\
\text { Makale } \\
2005\end{array}$ & $\begin{array}{l}\text { - Yerleşikliğin rekabet avantajı } \\
\text { yaratmadaki rolü ve ağ analizinin } \\
\text { örgütsel araştırmalardaki önemi nedir? }\end{array}$ & $\begin{array}{l}\text { - Yerleşiklik sosyal ağ ve } \text { sosyal } \\
\text { sermaye yoluyla sahip olunan rekabet } \\
\text { avantajının taklidini önler. Rekabet } \\
\text { avantajının sürekliliğini r sosyal } \\
\text { sermayenin gücü sağlar. }\end{array}$ \\
\hline $\begin{array}{c}\text { İçsel ve Dışsal Sosyal Sermaye } \\
\text { Yaklaşımları Açısından Türk } \\
\text { Toplumunun Sosyal Sermaye } \\
\text { Potansiyeli }\end{array}$ & $\begin{array}{l}\text { ÖZEN Ş. } \\
\text { ASLAN Z. } \\
\text { Makale } \\
2006\end{array}$ & $\begin{array}{l}\text { - Sosyal sermaye yaklaşımına göre Türk } \\
\text { toplumunun sosyal sermaye } \\
\text { potansiyeli farklılaşabilmektedir. }\end{array}$ & 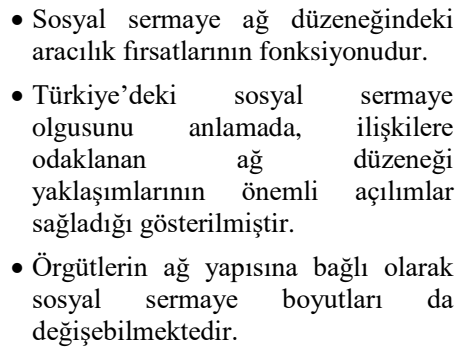 \\
\hline $\begin{array}{c}\text { Sosyal Sermaye: Yapının Sunduğu } \\
\text { Bir Olanak mı, Yoksa Bireyin amaçlı } \\
\text { Eylemi? }\end{array}$ & $\begin{array}{l}\text { SARGUT S. } \\
\text { Makale } \\
2006\end{array}$ & $\begin{array}{l}\text { - Sosyal sermaye bireysel eylemle mi } \\
\text { yoksa sosyal yapida yerleşik ilişkiler } \\
\text { sonucu mu oluşur? }\end{array}$ & $\begin{array}{l}\text { - Ağ düzeneğine ilişkin çalışmalar ile } \\
\text { sosyal sermaye kavramını } \\
\text { anlaşılmasına katkı sunar. } \\
\text { - Bireyselci ve Yapısalcı yaklaşımlar } \\
\text { ile ağ düzeneğinin çözzümlemesi } \\
\text { yapılabilir. }\end{array}$ \\
\hline $\begin{array}{c}\text { Sosyal Sermayenin Ağbağ } \\
\text { Kuram(lar)1: Dayanışmacı ve Aracı } \\
\text { Sosyal Sermaye }\end{array}$ & $\begin{array}{l}\text { ÖZTAŞ N. } \\
\text { Makale } \\
2007\end{array}$ & $\begin{array}{l}\text { - Bir aktörün daha iyi bağlantılarının ve } \\
\text { konumunun olması ne demektir? }\end{array}$ & $\begin{array}{l}\text { - Sosyal sermaye kuramı, zayıf ve } \\
\text { güçlü bağlar, yoğunluk ve köprü gibi } \\
\text { geçerlilikleri test edilmiş yöntemler } \\
\text { sayesinde analitik } \\
\text { kazanmıştır. }\end{array}$ \\
\hline
\end{tabular}


ÇUBUKCU, Murat - Örgütler Arası Ağların Stratejik Önemine Dair Literatürdeki Güncel Tartışmalar

\begin{tabular}{|c|c|c|c|}
\hline $\begin{array}{l}\text { Sosyal Yerleşiklik ve Örgütsel Ağ } \\
\text { Düzeneklerinin Yapısi: Sektörde } \\
\text { Gruplaşma ve Devlete Bağımlılık } \\
\text { Üzerine Görgül Bir Çalışma }\end{array}$ & $\begin{array}{l}\text { SARGUT S. } \\
\text { SÖZEN C.H. } \\
\text { Bildiri } \\
2008\end{array}$ & $\begin{array}{l}\text { - Örgütlerin kurdukları ağ ilişskilerinin } \\
\text { niteliği ve yönü nedir? }\end{array}$ & $\begin{array}{l}\text { - Araştırmanın bulguları gruplaşmanın } \\
\text { yüksek olduğ ve devletin } \\
\text { müdahalesinin düşük olduğu } \\
\text { durumlarda örgütlerin ortak özellikte } \\
\text { olan diğerleriyle yerleşik ilişkiler } \\
\text { kurabileceğini göstermektedir. } \\
\text { - Araştırmanın bulguları kuramsal } \\
\text { çerçeveyi desteklemektedir. Farklı } \\
\text { gruplan temsil eden örgütlerin } \\
\text { bulunduğu ve devletin müdahalesinin } \\
\text { düşük olduğu bir alanda "biz ve } \\
\text { onlar" ayrımının belirginleştiği ifade } \\
\text { edilebilir. Bu durum, gruplar aras1 } \\
\text { rekabeti artıracağından aynı gruptan } \\
\text { olan aktörler kendi aralarında sosyal } \\
\text { nitelikli güçlü bağlar oluştururken } \\
\text { diğer gruptaki firmalara uzak } \\
\text { duracaklarını göstermektedir. }\end{array}$ \\
\hline $\begin{array}{c}\text { Sosyal Ağ Özellikleri Bakış Açısıyla } \\
\text { Sosyal Sermaye ve Bilgi Yaratma } \\
\text { İlişkisi }\end{array}$ & $\begin{array}{l}\text { ÖZDEMIR A.A. } \\
\text { Makale } \\
2008\end{array}$ & $\begin{array}{l}\text { - Sosyal ağ kuramlarına göre bilgi elde } \\
\text { etme ve sosyal sermaye arasındaki } \\
\text { ilişki nasıldır? }\end{array}$ & $\begin{array}{l}\text { - Bilgi yaratma ve Sosyal sermaye } \\
\text { arasındaki ilişki bilim dallarına göre } \\
\text { değişmektedir. }\end{array}$ \\
\hline $\begin{array}{l}\text { Social Networks Versus Technical } \\
\text { Networks: How Different Social } \\
\text { Interaction Patterns Effect } \\
\text { Information System Utilization in the } \\
\text { Organizations? }\end{array}$ & $\begin{array}{l}\text { SÖZEN C.H. } \\
\text { SAĞSAN M. } \\
\text { Makale } \\
2009\end{array}$ & $\begin{array}{l}\text { - Taraflar arasında sosyal ilişkilerin } \\
\text { kurulmasının nedenleri? } \\
\text { - Sosyal sistemler içindeki gizli } \\
\text { dinamiklerin olası etkilerini nelerdir? }\end{array}$ & $\begin{array}{l}\text { - Sosyolojideki geleneksel } \\
\text { yaklaşımlardan oldukça farklı olan } \\
\text { sosyal ağ çalışsmaları, örgütsel ağları } \\
\text { anlamak ve işlemek için çok yararlı } \\
\text { araçlar olabilir. } \\
\text { - Çeşitli araştırma faaliyetlerinin } \\
\text { sonuçları, aktörlerin sosyal } \\
\text { bağlantılarını bilgiye, kaynaklara ve } \\
\text { olası firsatlara ulaşmak için } \\
\text { kullandıklarını göstermiştir. } \\
\text { - Bir örgütte çok sayıda yapısal boşluk } \\
\text { varsa, örgüt ağlarındaki bazı aktörler } \\
\text { için bir dizi aracılık firsatı da } \\
\text { olacaktır. } \\
\text { - Bu çalışma, yapısal boşluklar teorisi } \\
\text { kullanarak örgütlerde sosyal olarak } \\
\text { oluşturulan bilgi akış yapılarıa bir } \\
\text { açıklama getirmeyi amaçlayan } \\
\text { kavramsal bir çerçeve sunmaktadır. }\end{array}$ \\
\hline $\begin{array}{l}\text { Örgütsel Ă̆ Düzenekleri ve } \\
\text { Yönetici Elitler }\end{array}$ & $\begin{array}{l}\text { KIRKBEŞOĞLU E. } \\
\text { SÖZEN C.H. } \\
\text { Makale } \\
2009\end{array}$ & $\begin{array}{l}\text { - Bu çalışmanın temel amacı özellikle } \\
\text { yönetim ve örgüt yazınında elit } \\
\text { aktörlerin örgütsel ağ düzenekleri } \\
\text { içerisindeki stratejik etkilerini } \\
\text { kuramsal açıdan ortaya koymaktır. } \\
\text { - Bu amaçla elit aktörlerin stratejik } \\
\text { etkilerini sosyal ağ düzenekleri } \\
\text { dahilinde ele alınıp kavramsal bir } \\
\text { model oluşturulmuştur. }\end{array}$ & $\begin{array}{l}\text { - Elit aktörler örgütsel yaşamda belirli } \\
\text { ilişkiler ağında ve karşlıklı faydalara } \\
\text { sebep olan kurallar dâhilinde farklı } \\
\text { aktörlerle etkileşim içerisinde yer } \\
\text { alırlar. Aktörler arası bu etkileşim } \\
\text { örgütlerin yeterli refah düzeyine ve } \\
\text { hatta meşruiyete ulaşmasını sağlamak } \\
\text { adına önemli olduğu gibi, aktörlerin } \\
\text { karş1lıkl davranışları da örgütsel } \\
\text { alanda oluşturulan bu ağ düzeneği } \\
\text { içerisine yerleşiktir. } \\
\text { - Elit aktörler örgütsel yaşamda, sahip } \\
\text { oldukları stratejik konum gereği } \\
\text { önemli avantajlara sahiptirler. Bu } \\
\text { kişiler sahip oldukları sermayeler } \\
\text { yardımıyla farkli aktörler arasında bir } \\
\text { köprü görevi üstlenir ve kendi } \\
\text { faydalarını azami düzeye çekme } \\
\text { gayretindedirler. }\end{array}$ \\
\hline $\begin{array}{l}\text { Kaynak Bağımlıllı̆̆ İşlem } \\
\text { Maliyetleri, } \\
\text { Örgütsel Ağ ve Yeni-Kurumsal } \\
\text { Kuram ile Örgütlerin İttifak } \\
\text { Oluşturma Sebepleri Üzerine Bir } \\
\text { İnceleme }\end{array}$ & $\begin{array}{l}\text { MEYDAN H.C. } \\
\text { Makale } \\
2010\end{array}$ & $\begin{array}{l}\text { - İşletmelerin kuramsal olarak ittifak } \\
\text { oluşturma nedenleri nelerdir? } \\
\text { - Örgütsel ağ ve yeni kurumsal kuram } \\
\text { çerçevesinde ittifak nedenleri nelerdir? }\end{array}$ & $\begin{array}{l}\text { - Farklı amaçlarla örgütler birbirleri ile } \\
\text { ilişki içine girerler. } \\
\text { - Örgütler ittifak yapmadan önce değer } \\
\text { analizleri yaparlar. }\end{array}$ \\
\hline $\begin{array}{c}\text { Sosyal Ağ Kuramlarının Bakış } \\
\text { Açısıyla Örgütlerde Çatışma } \\
\text { Yönetimi }\end{array}$ & $\begin{array}{l}\text { SÖZEN C.H. } \\
\text { ESATOĞLU A.E. } \\
\text { Makale } \\
2010\end{array}$ & $\begin{array}{l}\text { - Ne tür ağ yapılanmaları ne gibi } \\
\text { sonuçlar ortaya çıkarır? } \\
\text { - Sosyal ağlarda merkezilik, yoğunluk } \\
\text { ve ağlarda yapısal boşluklar ile } \\
\text { aracılı rolleri gibi unsurlar } \\
\text { kullanılarak aktörlerin algıları ile }\end{array}$ & $\begin{array}{l}\text { - Bu çalışmada, örgütlerde çatışma } \\
\text { yönetimi sosyal ağ kuramı } \\
\text { bağlamında kavramsal bir çerçevede } \\
\text { sunulmuştur. } \\
\text { - Sosyal ağ araştırma yöntemi, sosyal } \\
\text { dinamiklerin daha iyi anlaşılmasını }\end{array}$ \\
\hline
\end{tabular}




\begin{tabular}{|c|c|c|c|}
\hline & & eylemlerini ne yönde etkilenebilir? & sağlar. \\
\hline $\begin{array}{c}\text { Örgütlerin İçinde Bulunduğu Ağ } \\
\text { Şebekelerindeki Konumlarının } \\
\text { Örgütsel Alandaki Eşbiçimliliğe } \\
\text { Etkisi }\end{array}$ & $\begin{array}{l}\text { CANBOLAT E.Ö. } \\
\text { Makale } \\
2010\end{array}$ & 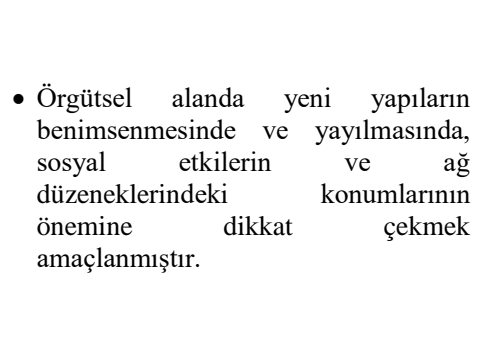 & $\begin{array}{l}\text { - Yerleşik ilişkilerden sağlanan } \\
\text { avantajlı konumları sosyal ağ } \\
\text { düzeneğinde örgütsel alana etkisi } \\
\text { olduğunu savunulmaktadır. } \\
\text { - Örgütsel eşbiçimlilik ve çeşitlilik } \\
\text { bağlamınndaki farkl1lıklar, güçlü ve } \\
\text { zayıf bağları ile açıklanırken, ağdaki } \\
\text { örgütlerin diğer özellikleri, yappssal } \\
\text { boşlukları, merkez-çevre bağları ile } \\
\text { değerlendirilmiştir. }\end{array}$ \\
\hline $\begin{array}{c}\text { Sosyal Ağlar, Ağ Araştırmaları ve } \\
\text { Uygulama Alanları }\end{array}$ & $\begin{array}{l}\text { SÖZEN C.H. } \\
\text { Makale } \\
2011\end{array}$ & $\begin{array}{l}\text { - Sosyal ağ araştırmalarının uygulama } \\
\text { alanları nelerdir? } \\
\text { - Sosyal ağ analizinin içeriği nedir? } \\
\text { - Sosyal ağ araştırmalarında sıklıkla } \\
\text { kullanılan yöntemler nelerdir? }\end{array}$ & $\begin{array}{l}\text { - Sosyal ă̆ analizleri, çoğunlukla bu } \\
\text { amaç için tasarlanmış özel yazılımlar } \\
\text { kullanılarak yapılmaktadır. } \\
\text { - Sosyal ağlar farklı uygulama } \\
\text { alanlarında kullanılmaktadır. Sosyal } \\
\text { ağ analizi aktörlerin aralarındaki } \\
\text { etkileşimlere odaklanmaktadır. }\end{array}$ \\
\hline $\begin{array}{c}\text { Social Networks and Power in } \\
\text { Organizations: A Research on the } \\
\text { Roles and Positions of the Junior } \\
\text { Level Secretaries in an Organizational } \\
\text { Network }\end{array}$ & $\begin{array}{l}\text { SÖZEN C.H. } \\
\text { Makale } \\
2012\end{array}$ & $\begin{array}{l}\text { - Sosyal ağ teorisi, yöneticiler ile } \\
\text { çalışanlar arasındaki sosyal bağların } \\
\text { nasıl öngörülemeyen sonuçlara yol } \\
\text { açabileceğini anlamalarına yardımcı } \\
\text { olabilir mi? } \\
\text { - Bazı organizasyonel pozisyonlar, odak } \\
\text { aktörlerine kuruluşlarda sosyal bağlar } \\
\text { kurma konusunda nasıl avantaj } \\
\text { sağlayabilecekleri? }\end{array}$ & $\begin{array}{l}\text { - Sonuçlar, çeşitli bağımlılıklar } \\
\text { yaratmak için sosyal bağlantıların } \\
\text { kullandıklarını göstermektedir. } \\
\text { - Bu araştırma, kuruluşlarda yüksek } \\
\text { güç potansiyeline sahip olanların ve } \\
\text { bir sosyal ağdaki güçlü konumlarının } \\
\text { bilincinde olanların bunu kendi } \\
\text { çıarları için kullanabileceğini } \\
\text { göstermektedir. }\end{array}$ \\
\hline $\begin{array}{c}\text { İş Sahiplerinin Sosyal Ağ } \\
\text { Bağlantılarının Girişimciden, } \\
\text { İkinci ve Üçüncü Kuşağa Değişimi }\end{array}$ & $\begin{array}{l}\text { TUZLUKAYA Ş.E. } \\
\text { SARGUT S.A. } \\
\text { SÖZEN C.H. } \\
\text { Bildiri } \\
2014\end{array}$ & $\begin{array}{l}\text { - Çalışmanın temel amacı, ağdüzeneği } \\
\text { kuramı araştırmalarında göz ardı } \\
\text { edilen değişim konusuna aç̧ılkama } \\
\text { getirmektir. Örgütlerde girşimciden, } \\
\text { ikinci ve üçüncü kuşağa doğru } \\
\text { gerçekleşen sahiplik değişiminin, } \\
\text { örgütler arasında kurulan sosyal ağ } \\
\text { düzeneklerini nitelik ve nicelik } \\
\text { açısından ne Şekilde değiştireceği } \\
\text { sorunsalından hareket etmektedir. }\end{array}$ & $\begin{array}{l}\text { - İş sahiplerinin, girişimciden üçüncü } \\
\text { kuşağa doğru değişiminin, örgütler } \\
\text { arası ağ düzeneklerinin değişimine } \\
\text { etkisi olduğu iddia edilmektedir. } \\
\text { - Araştırmanın bulgularına göre, iş } \\
\text { sahiplerinin girişimciden üçüncü } \\
\text { kuşağa değişimi, örgütlerarası } \\
\text { düzeydeki güçlü bağları oranını } \\
\text { azaltmaktadır. Bu noktada, sahiplik } \\
\text { değişimi sürecinde, yeni kuşaklarda } \\
\text { yapsal boşlukların ve aracıların } \\
\text { öneminin artacağı fikri } \\
\text { desteklenmektedir. }\end{array}$ \\
\hline $\begin{array}{l}\text { Organizational Network Effect } \\
\text { On Diversification Strategies }\end{array}$ & $\begin{array}{l}\text { CANBOLAT, E.Ö. } \\
\text { Makale } \\
2014\end{array}$ & $\begin{array}{l}\text { - Ağ niteliklerini kullanmada farklı olan } \\
\text { iş gruplarının çeşitlendirme } \\
\text { stratejilerinde de farklılaşıp } \\
\text { farklılaşmadıkları? } \\
\text { - Ağ üyelerinin merkez ve çevre } \\
\text { açısından konumların, yapısal } \\
\text { boşlukları kapsayan rollerini ve } \\
\text { çeşitlendirme stratejilerini belirler mi? }\end{array}$ & $\begin{array}{l}\text { - Merkezde bulunan ve daha yüksek } \\
\text { aracıllk oranlarına sahip iş } \\
\text { gruplarının çeşitlendirme stratejileri } \\
\text { kapsa-mında farklılaştığı tespit } \\
\text { edilmiştir. } \\
\text { - Bu çalışmada, stratejik yapiların } \\
\text { kuruluşlar tarafindan benimsenmesi } \\
\text { açısından bir sivil toplum örgütü } \\
\text { grubu arasındaki ağ yapısının etkisi } \\
\text { bulunmuştur. }\end{array}$ \\
\hline $\begin{array}{c}\text { An Alternative Forms of Organizing } \\
\text { Business Model: A Model of Value } \\
\text { Creater Networks }\end{array}$ & $\begin{array}{l}\text { CANBOLAT E.Ö. } \\
\text { BAŞ A. } \\
\text { CAFRI R. } \\
\text { Bildiri } \\
2014\end{array}$ & $\begin{array}{l}\text { - A } \breve{g} \text { modellerinin değer yaratma } \\
\text { üzerindeki etkisi nedir? } \\
\text { - Örgütler arası ilişkilerden kaynaklanan } \\
\text { ağ modalitelerinin ağa gömülü } \\
\text { firmaların değer yaratmalarını nasıl } \\
\text { etkiler? }\end{array}$ & $\begin{array}{l}\text { - Buradaki temel fikir, bireylerin } \\
\text { makro yapılara bağlanma } \\
\text { biçimlerinin genellikle yerel } \\
\text { bağlantıları aracılı̆̆ıla olmasıdır. } \\
\text { Aktörleri en doğrudan sınırlayan ve } \\
\text { onlara firsatlara erişim sağlayan yerel } \\
\text { bağlantılardır. } \\
\text { - Ego ağlarının franchise alanlarının } \\
\text { incelenmesi, bir kurumun değerinin } \\
\text { neden diğerlerinden farklı olduğu } \\
\text { konusunda fikir verebilir. Mikro } \\
\text { açıdan, bir popülasyondaki ego } \\
\text { ağlarının demografisine bakmak, bize } \\
\text { farklılaşma ve uyum hakkında biraz } \\
\text { bilgi verebilir. }\end{array}$ \\
\hline
\end{tabular}


ÇUBUKCU, Murat - Örgütler Arası Ağların Stratejik Önemine Dair Literatürdeki Güncel Tartışmalar

\begin{tabular}{|c|c|c|c|}
\hline $\begin{array}{l}\text { Marketing Strategy Choice Of } \\
\text { Members Of a Franchise Network: } \\
\text { The Case Of Simit Saray1 }\end{array}$ & $\begin{array}{l}\text { CANBOLAT E.Ö. } \\
\text { ÇELIKSOY E. } \\
\text { Makale } \\
2015\end{array}$ & $\begin{array}{l}\text { - Bir imalat firması katma değeri } \\
\text { yüksek bir rekabet avantajı elde } \\
\text { etmeyi nasıl başardı? } \\
\text { - Ağın bir ortağı olmak ve } \\
\text { perakendecilik ağının avantajlarını } \\
\text { elde etmek, global bir perakende } \\
\text { olmak için gerekli şartları ya da yeterli } \\
\text { koşulları sağlıyor mu? }\end{array}$ & $\begin{array}{l}\text { - Bir franchise ağının üyelerinin } \\
\text { pazarlama stratejisi seçimi, bu ağdaki } \\
\text { yapısal konumları ile ilgili olabilir. } \\
\text { - İşletmelerin yüksek katma değerli bir } \\
\text { rekabet avantaji elde etmesi, ağ } \\
\text { modaliteleri ile ifade edilmektedir. } \\
\text { - Bu çalışma, ağ yapısının bir grup } \\
\text { örgütte etkisini araştırmıştır. Ağların } \\
\text { stratejik yönetim süreçleri ve } \\
\text { uygulamaları üzerindeki etkilerini } \\
\text { analiz etmeyi amaçlamıştır. Sosyal } \\
\text { faktörlerin örgütsel alan üzerindeki } \\
\text { etkisi ifade edilmiştir. }\end{array}$ \\
\hline $\begin{array}{c}\text { Biçimsel ve Biçimsel Olmayan Sosyal } \\
\text { Ağların Sosyal Sermaye Edinimindeki } \\
\text { Rolü: Kadın Yönetim } \\
\text { Kurulu Üyeleri Üzerine Bir Araştırma }\end{array}$ & $\begin{array}{l}\text { ALAN H. } \\
\text { SÖZEN C.H. } \\
\text { Makale } \\
2017\end{array}$ & $\begin{array}{l}\text { - Sosyal ağlar içerisinde kadın yönetim } \\
\text { kurulu uyyelerinin formel ve informel } \\
\text { ağlarda bulunma eğilimlerinin fazla } \\
\text { olmasının sosyal sermaye } \\
\text { edinimindeki rolü nedir? }\end{array}$ & $\begin{array}{l}\text { - Kariyerlerinin gelişiminde kadın } \\
\text { yöneticilerin informel ağ ilişkilerinin } \\
\text { sosyal sermayelerini artırmaları } \\
\text { beklenir. }\end{array}$ \\
\hline $\begin{array}{c}\text { Türkiye'de KOBI'lerin Şebeke } \\
\text { Organizasyonlara Katılma Nedenleri } \\
\text { Üzerine Bir Araştırma }\end{array}$ & $\begin{array}{l}\text { ENSARİ M.Ş. } \\
\text { KARABAY M.E. } \\
\text { Makale } \\
2017\end{array}$ & $\begin{array}{l}\text { - Türkiye'de KOBİ'lerin örgütler arası } \\
\text { ağlar içerisinde bulunma nedenleri } \\
\text { işletmenin yaşına, menşeine ve } \\
\text { sektörüne göre değişir mi? }\end{array}$ & $\begin{array}{l}\text { - Uzun süredir faaliyet gösteren yaşlı } \\
\text { işletmeler, daha genç işletmelere göre } \\
\text { iş birliklerinde daha çok maliyet } \\
\text { düşürmek amacındadırlar. } \\
\text { - Yerel işletmelerin partner seçimi ve } \\
\text { iş birliği düzeyi bakımından sektörler } \\
\text { arasında anlamlı farklılıkların } \\
\text { olduğunu göstermektedir. }\end{array}$ \\
\hline $\begin{array}{l}\text { Asil-Vekil İlişkilerinin Kültürel } \\
\text { Bağlamda Sosyal Ağ Kuramı } \\
\text { Çerçevesinde Sosyal Ağ Analizi } \\
\text { Kullanılarak İncelenmesi }\end{array}$ & $\begin{array}{l}\text { TUNÇAY S.S. } \\
\text { ÖZER P.S. } \\
\text { Makale } \\
2017\end{array}$ & $\begin{array}{l}\text { - Kültürel bağlamda ve sosyal ağ } \\
\text { kuramı çerçevesinde asil ve vekil } \\
\text { ilişkilerinin çerçevesi incelenmektedir. }\end{array}$ & $\begin{array}{l}\text { - Sosyal ağ analizi, aktörlerden oluşan } \\
\text { ağın görselleştirilmesine çeşitli } \\
\text { yazılım programları vasitasıyla izin } \\
\text { verir. } \\
\text { - İlişkilerin önemi üzerine odaklanan } \\
\text { sosyal ağ kuramında, bireyler arası } \\
\text { ilişkiler çerçevesinde incelemenin } \\
\text { önemli olduğu söylenebilir }\end{array}$ \\
\hline $\begin{array}{l}\text { Social Networks and Innovation } \\
\text { in Industrial Clusters: A Study } \\
\text { in case of Turkish Industrial Clusters }\end{array}$ & $\begin{array}{l}\text { KARAKAYACI Ö. } \\
\text { DINÇER İ. } \\
\text { Makale } \\
2018\end{array}$ & $\begin{array}{l}\text { - Sanayi kümelerinde formel ve } \\
\text { informel bağlantılar yenilikçi } \\
\text { aktivitelerin gelişiminde belirleyici bir } \\
\text { etkiye sahiptir. } \\
\text { - Sanayi kümelerinin gelişiminde sosyal } \\
\text { sermaye ve sosyal ağların rolü nedir? }\end{array}$ & $\begin{array}{l}\text { - Sosyal ağ türleri literatürde } \\
\text { belirtildiği gibi farklı bilgi } \\
\text { kaynaklarna erişebildiği sürece } \\
\text { yenilikçi etkinliklere } \\
\text { bulunabilirler. } \\
\text { - Resmi olmayan bağlantıların resmi } \\
\text { ve kurumsal bağlantılar gibi ürün } \\
\text { inovasyonunu artırma roünü } \\
\text { üstlenebileceğini göstermektedir. } \\
\text { - Sosyal ağların inovasyon üzerindeki } \\
\text { etkileri kümeden kümeye farklılık } \\
\text { göstermektedir. }\end{array}$ \\
\hline
\end{tabular}

Kaynak: Yazar tarafından hazırlanmıştır.

Tablo 2'de görüldüğü gibi, yerel literatürdeki örgütler arası ağların önemine dair tartışmalarda; örgütlerin kendilerine fayda sağlayabilecek ağ ilişkileri oluşturma eğiliminde oldukları, örgütlerin kurdukları ağ ilişkilerinin niteliği ve yönü üzerine tartışmalar olduğu, örgütler arası ilişkilerin yerleşikliğinin esnekliği sınırladığı, iş insanlarının sosyal ağlarının girişimcilik sürecinde performanslarını doğrudan etkilediği, yerleşikliğin, sosyal ağ ve sosyal sermaye yoluyla sahip olunan rekabet avantajının taklidini önlediği, yerleşik ilişkilerden sağlanan avantajlı konumların sosyal ağ düzeneğinde örgütsel alana etkisi olduğu iddia edilmektedir. Ayrıca yapılan araştırmalarda görüldüğü gibi, politik güce sahip ve merkezde yer alan örgütlerin yeniliklere daha hızlı uyum sağladığı ve ağ düzeneğindeki ilişki özellikleri ile yenilik süreçleri arasında anlamlı bir ilişki bulunduğu ve bir sosyal ağdaki güçlü konumlarının bilincinde olan kişilerin bunu kendi çıkarları için kullanabileceği tespit edilmiştir.

Hem yerel hem de uluslararası literatürde aktörlerin bireysel ve örgütsel başarılara ulaşma yolunda sosyal ağlarını bilinçli olarak kullandıkları yönünde çalışmalar, araştırmalar ve tartışmalar olduğu görülmüştür. Türkiye bağlamında sosyal ağların niteliğinin ve kullanma biçimlerinin yerleşik olduğu bağlamdan etkilendiği ve sosyal ağ kuramının geliştirildiği ve ağırlıkla araştırıldığı ülkelerden farklı sonuçlar üretebildiği tespit edilmiştir. 


\section{TARTIŞMA VE SONUÇ}

Literatürde ağ düzenekleri içerisine yerleşik örgütlerin, bu sisteme dahil olmayanların sahip olamayacağ 1 kaynak ve bilgilere ulaşabileceği ve bir ağa dahil olmanın sağlayabileceği avantajlar konularının tartışıldığ 1 tespit edilmiştir. Literatürde kaynak bağımlılı̆̆ı (Pfeffer ve Salancik, 1978), örgütler arası ağ (Baker ve Faulkner, 2002) ve makro kurumsalcı (Whitley, 2000) yaklaşımlarda örgütlerin diğer örgütlerle ilişkilerinde yerleşik ilişkilerin ve sektörlerinin devlete bağımlılık düzeylerinin etkisi olduğunun öne sürüldüğü görülmektedir

Çalışmamızda örgütler arası ağlara dâhil olmanın stratejik etkisi ve bu etkinin önemi üzerine yapılan literatürdeki tartışmalar ortaya konulmuştur. Uluslararası ve ulusal literatürde ağlara ilişkin tartışmalar temel soruları, konuları ve bulguları ile kronolojik olarak tablolar şeklinde Tablo 1 ve Tablo 2'de sunulmuştur. Uluslararası ve ulusal akademik tarama sitelerinin, 1970 ila 2018 yılları arası yapılan tarama sonucunda, ağlar konusunda, 80 uluslararası ve 27 ulusal makale incelenmiş ve konu, temel araştırma soru ve bulguları ile ekte yer verilmiştir. Böylelikle örgütler arası ağlara ilişkin çıkarımlar yapmaya olanak tanınmaktadır.

Araştırma kapsamında konuyla ilgili hem ulusal hem de uluslararası literatür ayrıntılı bir biçimde taranmıştır. Özellikle ağ kavramları ve ağlara katılma nedenlerinin tespitine yönelik ulusal literatürde kısıtlı sayıda çalışma olduğu tespit edilmiştir. Uluslararası yazında ise çeşitli teorik ve uygulamalı çalışmalara rastlanmış, yapılan en eski çalışmalardan en güncel çalışmalara kadar bütün çalışmalar taranarak konuyla ilgili kapsamlı bir kavramsal çerçeve oluşturulmuştur. Ulusal ve uluslararası literatürde yer alan akademik çalışmalar kronolojik sıra ile tablolar halinde temel konu ve bulguları ile sıralanmıştır. Ayrıca ayrıntılı bir ulusal ve uluslararası literatür taraması ile kronolojik olarak yapılan çalışmaların, temel konu ve bulguları ile ortaya konulması da sağlanmıştır. Dolayısıyla bu çalışmanın Türkiye'deki örgütler arası ağlar literatürüne önemli katkı sağlaması beklenmekte ve gelecekte yapılacak olan çalışmalara öncü niteliği taşıyacağı varsayılmaktadır.

Araştırma kapsamında hem yerel hem de uluslararası yazın, ayrıntılı bir biçimde uluslararası ve ulusal akademik indekslerde taranmıştır. Özellikle örgütler arası ağ düzenekleri ve girişimcilerin sahip olmuş oldukları enformel ağlar hakkında yerel yazında kısıtlı sayıda çalışma olduğu tespit edilmiştir. Uluslararası yazında ise özellikle, uluslararası akademik indeks ve tarama sitelerinde teorik ve uygulamalara yönelik akademik makalelere rastlanmıştır. 1970'li yılardan günümüze kadar yapılmış olan en eski çalışmalardan en güncel çalışmalara (2021 tarihli gibi) ilgili konu taranarak konuyla ilgili kapsamlı bir kavramsal çerçeve oluşturulmuştur.

Konuyla ilgili kavramsal bir çerçeve oluşturulurken ilk olarak ağ, örgütler arası ağ, sosyal sermaye, stratejik a $\breve{g}$ ve enformel ağlar kavramları ile ilgili tarama yapılarak kavramsal çerçevede bu kavramların tanımlarına, boyutlarına ve özelliklerine yer verilmiştir. Ayrıca hem örgütler arası ağlar hem de sosyal sermaye ve girişimcilik arasındaki ilişki üzerine yapılmış olan geçmiş çalışmalara yer verilmiş; söz konusu çalışmaların amaçları, yöntemleri ve ulaştıkları sonuçlar sıralanmıştır.

$\mathrm{Bu}$ yaklaşımın benimsenmesindeki amaç, dünya genelinde yapılmış örgütler arası ă ve enformel ă̆ çalışmalarındaki çeşitli yöntem ve bulguları ortaya çıkarmak ve ulaşılan sonuçları özetlemektir. Literatür taraması sonucunda mevcut tartışmalar çerçevesinde, örgütler arası ağlar içerisinde bulunmanın örgüt performansı üzerinde çeşitli etkileri olduğuna dair bazı tartışmalar olduğu tespit edilmiştir.

Ulusal ve uluslararası akademik çalışmalar metodolojik ve tematik açıdan incelenmiş ve konu hakkındaki literatürün çerçevesi kuramsal olarak belirlenmiş ve yapılan araştırmalar kavramsal çerçevede ortaya konulmuştur. İlgili kuramsal çerçeve örgütler arası ağlar literatürüne dayanılarak hazırlanan bu çalışmanın, bu alanda çalışan ve ileride çalışmayı düşünen araştırmacı ve uygulayıcılara katkı sağlaması umulmaktadır. Türkiye'de bu konuda yapılan araştırmaların sınırlı olması dolayısıyla bu çalışmanın ilgili literatürün zenginleşmesine olumlu bir etkisi olması beklenmektedir. 


\section{KAYNAKÇA}

ADLER, Paul ve KWON, Seok Woo (2002), "Social Capital: Prospects for a New Concept", Academy of Management Review, S.27(1), ss.17-40.

ALDRICH, Howard E. ve PFEFFER, Jeffrey (1976), "Environments of Organizations", Annual Review of Sociology, S.2, ss.79-105.

ALEKSIC, Ana ve JELAVIC, Sanda Rasic (2017), "Testing for Strategy-Structure Fit and Its Importance for Performance", Management, S.22, ss.85-102.

AXELSSON, Björn ve EASTON, Geoffrey (1992), Industrial Networks: A New View of Reality, Routledge Publisher, London and New York.

BARNEY, Jay B. (1991), "Firm Resources and Sustained Competitive Advantage”, Journal of Management, S.17(1), ss.99-120.

BARNEY, Jay B. ve WRIGHT, Patrick M. (1998), "On Becoming a Strategic Partner: The Role of Human Resources in Gaining Competitive Advantage", Human Resource Management, S.37(1), ss.31-46.

BAUM, Joel A. C. ve OLIVER, Christine (1991), "Institutional Linkages and Organizational Mortality", Administrative Science Quarterly, S.36(2), ss.187-218.

BLASCHKE, Steffen, SCHOENEBORN, Dennis ve SEIDL, David (2012), “Organizations as Networks of Communication Episodes: Turning the Network Perspective Inside Out", Organization Studies, S.33(7), ss.879-906.

BOURDIEEU, Pierre (1983), "The Field of Cultural Production, or: The Economic World Reversed", Poetics, S.12(4-5), ss.311-356.

BURT, Ronald S. (1992), Structural Holes: The Social Structure of Competition, Harvard University Press, Cambridge (US).

BURT, Ronald S. (1997), “A Note on Social Capital and Network Content”, Social Networks, S.19, ss.355-374.

BURTON, Richard M. ve OBEL, Borge (2004), Strategic Organizational Diagnosis and Design: The Dynamics of Fit, Springer Science HBusiness Media Publisher, New York (US), 3.Edition.

CARRINGTON, Peter J., SCOTT, John ve WASSERMAN, Stanley (2005), Models and Methods in Social Network Analysis, Cambride University Press, New York (US).

CASTELLS, Manuel (1996), The Rise of the Network Society, Blackwell Press, Oxford (UK).

CASTELLS, Manuel (2000), "Materials for an Exploratory Theory of the Network Society”, British Journal of Sociology, S.51(1), ss.5-24.

CHRISTAKIS, Nicholas ve FOWLER, James (2012), Sosyal Ağların Şaşırtıcı Gücü ve Yaşantımızı Biçimlendiren Etkisi, Varlık Yayınları, İstanbul.

COLEMAN, James S. (1988), "Social Capital in the Creation of Human Capital", American Journal of Sociology, S.94, ss.95-120.

COLEMAN, James S. (1990), Foundations of Social Theory, The Belknap Press of Harvard University Press, London (UK).

DYER, Jeffrey H. ve NOBEOKA, Kentaro (2000), "Creating and Managing a High-Performance KnowledgeSharing Network: The Toyota Case”, Strategic Management Journal, S.21(3), ss.345-367.

GERHART, Barry (2009), "How Much Does National Culture Constrain Organizational Culture?", Management and Organization Review, S.5(2), ss.241-259.

GRANDORI, Anna ve SODA, Giuseppe (1995), "Inter-Firm Networks: Antecedents, Mechanisms and Forms", Organization Studies, S.16(2), ss.183-214.

GRANOVETTER, Mark (1973), "The Strenght of Weak Ties", The American Journal of Sociology, S.78(6), ss.1360-1380. 
GRANOVETTER, Mark (1983), "The Strenght of Weak Ties: A Network Theory Revisited", Sociological Theory, S.1, ss.201-233.

GRANOVETTER, Mark (1985), "Economic Action and Social Structure: The Problem of Embeddedness", American Journal of Sociology, S.91(3), ss.481-510.

GULATI, Ranjay ve GARGIULO, Martin (1999), "Where Do Interorganizational Networks Come From?", American Journal of Sociology, S.104(5), ss.1439-1493.

GULATI, Ranjay, NOHRIA, Nitin ve ZAHEER, Akbar (2000), "Strategic Networks", Strategic Management Journal, S.21(3), ss.203-215.

HANNAN, Michael T. ve FREEMAN, John (1977), "The Population Ecology of Organizations", American Journal of Sociology, S.82(5), ss.929-964.

HARRIGAN, Kathryn R. (1985), “An Application of Clustering for Strategic Group Analysis”, Strategic Management Journal, S.6(1), ss.55-73.

HOFSTEDE, Geert (1980), Culture's Consequences: İnternational Differences in Work-Related Values, Sage Publisher, Beverly Hills - CA (US).

KANTUR, Deniz (2017), "Sosyal Girişimcilikte Yerleşiklik: Coğrafi Yayılım ve Kültürel Değerlerin Rolü”, Girişimcilik ve İnovasyon Yönetimi Dergisi, S.6(1), ss.173-196.

KATZ, Nancy, LAZER, David, ARROW, Holly ve CONTRACTOR, Noshir (2004), "Network Theory and Small Groups", Small Group Research, S.35(3), ss.307-332.

KILDUFF, Martin ve TSAI, Wenpin (2003), Social Networks and Organizations, Sage Publications, London (UK).

KILLING, Peter (1983), Strategies for Joint Venture Success, Praeger Publisher, New York (US).

KOGUT, Bruce (2000), "The Network as Knowledge: Generative Rules and Emergence of Structure", Strategic Management Journal, S.21, ss.405-425.

KOZAN, Kâmil M. ve AKDENIZ, Levent, (2014), "Role of Strong Versus Weak Networks in Small Business Growth in an Emerging Economy", Administrative Sciences, S.4, ss.35-50.

LUO, Yadong ve PARK, Seung H. (2001), "Strategic Alignment and Performance of Market Seeking MNCs in China", Strategic Management Journal, S.22(2), ss.141-155.

LUTHANS, Fred (2007), "Hope, Optimism and Other Business Assets: Why Psychological Capital is so Valuable to Your Company", Gallup Management Journal, January 11, http://gmj.gallup.com, (Erişim Tarihi: 13.07.2021).

LUTHANS, Fred, AVEY, James, AVOLIO Bruce, NORMAN, Steven ve COMBS, Gwendolyn (2006), "Psychological Capital Development: Toward a Micro Intervention", Journal of Organizational Behavior, S.27(3), ss.387-393.

MIERSCH, Yvonne T. (2017), "Beyond Trust: Towards a Practice-Based Understanding of Governing Network Organizations", Journal of Management \& Governance, S.21(2), ss.473-498.

MILES, Raymond E. ve SNOW, Charles C. (1984), "Designing Strategic Human Resources Systems", Organizational Dynamics, S.13(1), ss.36-52.

MILES, Raymond E. ve SNOW, Charles C. (1995), "The New Network Firm: A Spherical Structure Built on A Human Investment Philosophy", Organizational Dynamics, S.23(4), ss.4-18.

MOLLER, Kristian ve HALINEN, Aino (2017), "Managing Business and Innovation Networks-From Strategic Nets to Business Felds and Ecosystems", Industrial Marketing Management, S.67, ss.5-22.

MOLLER, Kristian, PARTANEN, Jukka, RAJALA, Arto, WESTERLUND, Mika, RAJALA, Risto ve SVAHN, Senja (2005), "Role of Partnerships and Networks in SME Innovation and Growth", The 21st Annual IMP Conference: Dealing with Dualities, 1-3 Septenber 2005, RSM Erasmus University Publisher, Rotterdam, https://www.impgroup.org/uploads/papers/4731.pdf (Erişim Tarihi: 03.05.2021).

MORGAN, Gareth (1997), Images of Organization, Sage Publisher, London (UK). 
NALEBUFF, Barry J. ve BRANDENBURGER, Adam M. (1997), "Co-Opetition: Competitive and Cooperative Business Strategies for The Digital Economy”, Strategy \& Leadership, S.25(6), ss.28-33.

OLIVER, Amalaya ve EBERS, Mark (1998), "Networking Network Studies: An Analysis of Conceptual Configurations in the Study of Inter-organizational Relationships", Organization Studies, S.19(4), ss.549-594.

ÖZDEVECIOĞLU, Mahmut (1995), “Organizasyon Kültürü", Stratejik Yönetim ve Liderlik (Ed. Mustafa Özel), İz Yayınları, İstanbul, 2. Bask1, ss.20-127.

ÖZEN, Şükrü ve ASLAN, Zuhal (2006), "İçsel ve Dışsal Sosyal Sermaye Yaklaşımları Açısından Türk Toplumunun Sosyal Sermaye Potansiyeli: Ortadoğu Sanayi ve Ticaret Merkezi (OSTIM) Örneği”, Akdeniz İïBF Dergisi, S.12, ss.130-161.

ÖZKAN CANBOLAT, Ela (2008), “Örgütsel Ă̆ Düzeneğinin Örgütsel Alandaki Çeşitlilik ve Değişime Etkisi: Çankırı Örneği”, Yayınlanmamış Doktora Tezi, Başkent Üniversitesi Sosyal Bilimler Enstitüsü, Ankara.

ÖZKAN CANBOLAT, Ela ve ÇELIKSOY, Emine (2015), "Marketing Strategy Choice of Members of a Franchise Network: The Case of Simit Sarayı", International Journal of Economics: Commerce and Management, S.III(1), ss.1-25.

PARTANEN, Jukka ve MOLLER, Kristian (2012), "How to Build a Strategic Network: A PractitionerOriented Process Model for the ICT Sector", Industrial Marketing Management, S.41(3), ss.481-494.

PFEFFER, Jeffrey ve SALANCIK, Gerald R. (1978), The External Control of Organizations: A Resource Dependence Perspective, Harper \& Row Publisher, New York (US).

PILOTTI, Luciano ve POZZANA, Roberto (1990), Forme Organizzative e Sistemi di Incentivi Dei Contratti di Franchising, CESCOM Bocconi, EGEA - Milan.

PODOLNY, Joel M. (2001), "Networks as the Pipes and Prisms of the Market", American Journal of Sociology, S.107(1), ss.33-60.

POLANYI, Karl (1944), The Great Transformation: the Political and Economic Origins of our Time, Rinehart \& Company Publisher, New York.

POLANYI, Karl (2001), The Great Transformation, Beacon Press, Boston.

POWELL, Walter W. ve DIMAGGIO, Paul J. (1991), The New Institutionalism in Organizational Analysis, University of Chicago Press, Chicago.

RAO, Hayagreeva, DAVIS, Gerald F. ve WARD, Andrew (2000), "Embeddedness, Social Identity and Mobility; Why Firms Leave the NASDAQ and Join the New York Stock Exchange", Administrative Science Quarterly, S.45(2), ss.268-292.

SARGUT, Selami A., VAROĞLU, Kadir, ÖZEN, Şükrü, OĞUZ, Fuat, SÖZEN, Cenk, YELOĞLU, Okan H. ve SAĞSAN, Mustafa (2007), Ulusal İş Sistemi ve Örgüt Ağları: Merkez-Çevre İkiliğinin Örgütler Arası İlişkilere Etkisi, Tübitak 106K174 Nolu Araştırma Projesi, Ankara.

SCOTT, John (2000), Social Network Analysis, Sage Publications, London, 2.Edition.

SHILS, Edward (2002), “Merkez ve Çevre”, Türkiye Günlüğü (Çev. Yusuf Ziya Çelikkaya), S.70, ss.86-96.

SUCHMAN, Mark C. (1995), "Managing Legitimacy: Strategic and Institutional Approaches", The Academy of Management Review, S.20(3), ss.571-610.

SUlLIVAN, Diane M. ve CAMERON, Ford M. (2014), "How Entrepreneurs Use Networks to Address Changing Resource Requirements During Early Venture Development", Entrepreneurship: Theory and Practice, S.38(3), ss.551-574.

THORELLI, Hans B. (1986), "Networks: Between Markets and Hierarchies", Strategic Management Journal, S.7(1), ss.37-51.

TICHY, Noel M., TUSHMAN, Michael L. ve FOMBRUN, Charles (1979), “Social Network Analysis for Organizations", The Academy of Management Review, S.4(4), ss.507-519. 
UZZI, Brian (1996), "The Source and Consequences of Embeddedness for the Economic Performance of Organizations: The Network Effect", American Sociological Review, S.61(4), ss.674-698.

UZZI, Brian (1997), "Social Structure and Competition in Interfirm Networks: The Paradox of Embeddedness", Administrative Science Quarterly, S.42(1), ss.35-67.

UZZI, Brian ve LANCHESTER, Ryon (2004), "Embeddedness and Price Formation in the Corporate Law Market", American Sociological Review, S.69(3), ss.319-344.

WALKER, Gordan, KOGUT, Bruce ve SHAN, Weijian (1997), "Social Capital, Structural Holes and the Formation of an Industry Network", Organization Science, S.8(2), ss.109-125.

WHITLEY, Richard (2000), "The Institutional Structuring of Innovation Strategies: Business Systems, Firm Types and Patterns of Technical Change in Different Market Economies", Organization Studies, S.21(5), ss.855-886.

XIE, Xuemei ve GAO, Yanru (2018), "Strategic Networks and New Product Performance: The Mediating Role of Ambidextrous Innovation", Technology Analysis \& Strategic Management, S.30(7), ss.811-824.

YELOĞLU, Hakkı O. ve SÖZEN, Cenk H. (2008), “Örgütsel Ekoloji Kuramı, Yerleşiklik Kavramı ve Kapanma Oranlarına Yönelik Önermeler", 16. Ulusal Yönetim ve Organizasyon Kongresi Bildiriler Kitabı, 1618 Mayıs 2008, İstanbul Kültür Üniversitesi Yayını, İstanbul, ss.243-247.

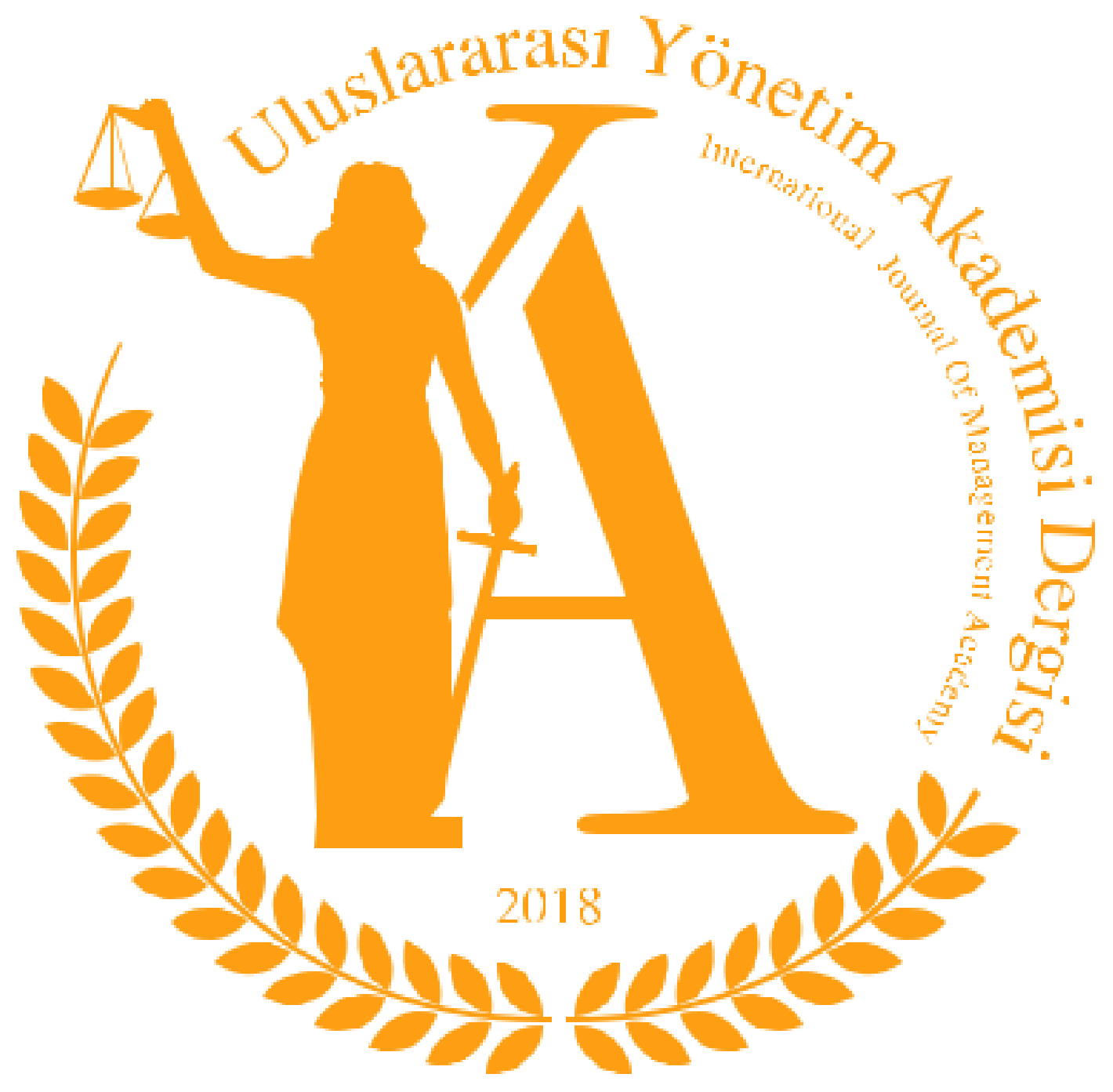

